\title{
Articles
}

\section{ANTITRUST ARBITRATION AND MERGER APPROVAL}

Mark A. Lemley \& Christopher R. Leslie

\begin{abstract}
In a string of recent opinions, the Supreme Court has made it harder for consumers to avoid arbitration clauses, even when businesses strategically insert provisions in them that effectively prevent consumers from being able to bring any claim in any forum.

Arbitration differs from litigation in ways that harm the interests of consumer antitrust plaintiffs. For example, arbitration limits discovery and has no meaningful appeals process. Furthermore, defendants use the terms in arbitration clauses to prevent class actions and to undercut the pro-plaintiff features of antitrust law, including mandatory treble damages, meaningful injunctive relief, recovery of attorneys' fees, and a lengthy statute of limitations.

The problems associated with antitrust arbitration are magnified in concentrated markets. Supporters of enforcing arbitration clauses assume that they these contractual provisions are the result of an informed, voluntary bargain. But when a market is dominated by a single supplier or a small group of firms, consumers often find it impossible to purchase a necessary product while retaining the right to sue, especially since arbitration clauses are generally embedded in contracts of adhesion. This means that in the markets most likely to be affected by antitrust violations, consumers are least likely to be able to avoid mandatory arbitration clauses.

Antitrust authorities can address the problem of proliferating arbitration clauses. We argue that antitrust officials should condition merger approval on the merging parties' agreement to not require arbitration of antitrust claims.
\end{abstract}

AUTHORS - (C) 2015 Mark A. Lemley \& Christopher R. Leslie. Mark A. Lemley is the William H. Neukom Professor of Law, Stanford Law School; partner, Durie Tangri LLP; Christopher R. Leslie is the Chancellor's Professor of Law, University of California Irvine School of Law. The authors thank Dan Crane, Chris Drahozal, Einer Elhauge, Jordan Elias, Joe Grundfest, Rose Hagan, Herb Hovenkamp, Cheryl Johnson, Tony Reese, 
NORTHWESTERN UNIVERSITY LA W RE VIEW

Danny Sokol, and participants at a workshop at the Federal Trade Commission for comments, and Madeleine Laupheimer for research assistance. 


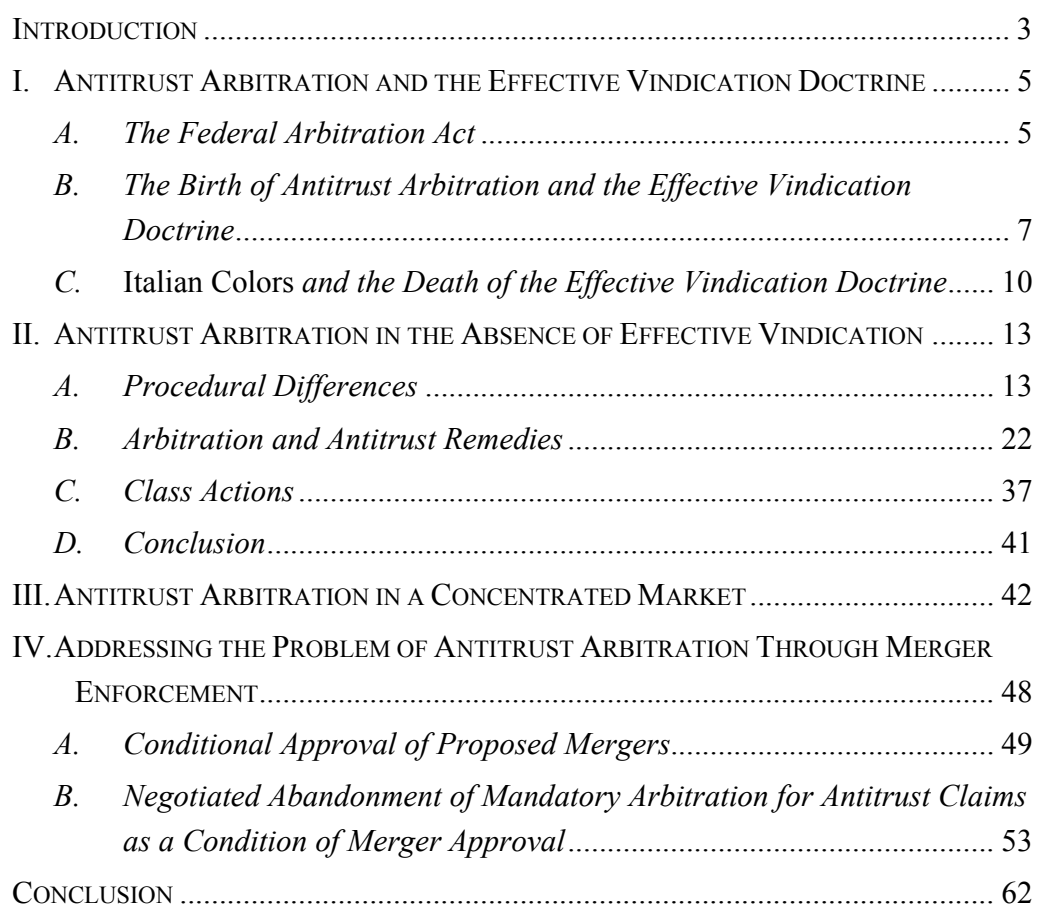

\section{INTRODUCTION}

In a string of recent opinions, the Supreme Court has made it harder for consumers to avoid arbitration clauses, even when businesses strategically insert provisions in them that effectively prevent consumers from being able to bring any claim in any forum. For example, when firms engage in illegal conduct that extracts small amounts of ill-gotten gains from millions of consumers, individual litigation (or arbitration) may cost more than the maximum possible recovery. In these scenarios, class action litigation or class-wide arbitration may be the only viable mechanisms for consumers to seek recovery. Yet, in AT\&T Mobility LLC v. Concepcion, ${ }^{1}$ the Supreme Court held that the Federal Arbitration Act preempted state laws that rendered class arbitration waivers in arbitration clauses unconscionable and, thus, unenforceable. In American Express Co. v. Italian Colors Restaurant, ${ }^{2}$ an antitrust case, the Court held that class action waivers embedded in mandatory arbitration clauses were enforceable even when they had the

\footnotetext{
1131 S. Ct. 1740 (2011).

2133 S. Ct. 2304 (2013).
} 
effect of making it economically irrational for the victims of antitrust violations to pursue their claims. ${ }^{3}$

Part I of this Article examines how courts initially treated antitrust claims as nonarbitrable. For decades, courts considered antitrust claims to be too complex and too important to trust to private arbitrators. By the 1980s, the Supreme Court permitted federal statutory rights, including antitrust claims, to be arbitrated so long as the plaintiffs could effectively vindicate their rights in the alternative forum (the so-called Effective Vindication Doctrine). In 2013, the Supreme Court in Italian Colors fundamentally weakened the Effective Vindication Doctrine when it held that arbitration clauses that precluded class actions and class-wide arbitration were enforceable even when they effectively prevented any victim from actually bringing an individual case.

Part II details the problems of mandatory arbitration of antitrust claims. Arbitration differs from litigation in ways that harm the interests of consumer-plaintiffs. For example, arbitration limits discovery and has no meaningful appeals process. Furthermore, defendants draft arbitration clauses to prevent class actions and to undercut the pro-plaintiff features of antitrust law, including mandatory treble damages, meaningful injunctive relief, recovery of attorneys' fees, and a lengthy statute of limitations. With the Court's undermining of the Effective Vindication Doctrine in Italian Colors, defendants' efforts to dismantle these pro-plaintiff components of antitrust law may prove more successful in the future.

Part III shows how the problems associated with antitrust arbitration are magnified in concentrated markets. Supporters of enforcing arbitration clauses assume that these contractual provisions are the result of an informed, voluntary bargain. But when a market is dominated by a single supplier or a small group of firms, consumers often find it impossible to purchase a necessary product while retaining the right to sue, especially since arbitration clauses are generally embedded in contracts of adhesion. This means that in the markets most likely to be affected by antitrust violations, consumers are least likely to be able to avoid mandatory arbitration clauses. Furthermore, when mergers result in concentrated markets, they can increase the problems explored in Part II.

Finally, Part IV explains how antitrust authorities can address the problem of proliferating arbitration clauses. When evaluating mergers, officials at the Federal Trade Commission and the Antitrust Division of the Department of Justice can threaten to challenge the merger unless the merging parties agree to specified conditions, such as the divestiture of

${ }^{3} I d$. at $2310-11$. 
certain assets. Because those mergers that pose the greatest risk of anticompetitive effects also magnify the problems associated with mandatory arbitration clauses, antitrust officials would be wise to condition merger approval on the merging parties' agreement to not require arbitration of antitrust claims. This Part explains the rationale and precedent for the antitrust agencies to impose such conditions.

\section{ANTITRUST ARBITRATION AND THE EFFECTIVE VINDICATION DOCTRINE}

\section{A. The Federal Arbitration Act}

Along with other common law traditions, the American legal system imported the English hostility to private arbitration as a substitute for public litigation. ${ }^{4}$ This resistance proved frustrating to supporters of commercial arbitration, ${ }^{5}$ who believed that private mediation was superior to traditional litigation because it was quicker, more efficient, and afforded the parties a degree of privacy unattainable in public litigation. ${ }^{6}$ Commercial arbitration was initially designed to settle trade disputes stemming from contracts. ${ }^{7}$ Private arbitration afforded commercial actors the ability to structure their own rules and to select adjudicators who understood the relevant industry, including its trade customs. ${ }^{8}$ The informality of the process, coupled with the arbitrators' expertise, could mean faster decisions delivered at a lower cost than full-blown litigation. ${ }^{9}$

Despite the perceived advantages of commercial arbitration, federal judges were not eager to cede their power to private arbitrators. ${ }^{10}$ In response to this judicial reluctance, Congress enacted the Federal Arbitration Act of

\footnotetext{
${ }^{4}$ Donald I. Baker \& Mark R. Stabile, Arbitration of Antitrust Claims: Opportunities and Hazards for Corporate Counsel, 48 Bus. LAw 395, 401 n.39 (1993).

${ }_{5}^{5}$ Christopher R. Leslie, The Arbitration Bootstrap, 94 TEX. L. REv. (forthcoming 2015).

6 Thomas Campbell, Roxane Busey, \& Peter Koch, Arbitrating Antitrust Claims-The Road Less Traveled, ANTITRUST, Fall 2004, at 8, 8.

7 See Leslie, supra note 5.

8 Thomas E. Dempsey, Case Comment, 44 Notre Dame Law. 279, 280-81 (1968) (“Commenting on the advantages of arbitration, Judge Learned Hand said: 'In trade disputes one of the chief advantages of arbitration is that arbitrators can be chosen who are familiar with the practices and customs of the calling, and with just such matters as what are current prices, what is merchantable quality, what are the terms of sale, and the like."” (quoting Am. Almond Prods. Co. v. Consol. Pecan Sales Co., 144 F.2d 448, 450 (2d Cir. 1944))).

9 AT\&T Mobility LLC v. Concepcion, 131 S. Ct. 1740, 1749 (2011) ("[T] $]$ he informality of arbitral proceedings is itself desirable, reducing the cost and increasing the speed of dispute resolution."); Lee Loevinger, Antitrust Issues as Subjects of Arbitration, 44 N.Y.U. L. REV. 1085, 1089 (1969).

10 See Baker \& Stabile, supra note 4, at 401 ("U.S. courts initially were hostile to the notion of permitting arbitration of antitrust disputes.").
} 
1925 (FAA). ${ }^{11}$ Section 2 of the Act provides that if a commercial contract contains an agreement to settle controversies arising from the contract through private arbitration, the promise to arbitrate "shall be valid, irrevocable, and enforceable, save upon such grounds as exist at law or in equity for the revocation of any contract." 12 The FAA repudiated "the longstanding judicial hostility to arbitration agreements that had existed at English common law and had been adopted by American courts, and ... place[d] arbitration agreements upon the same footing as other contracts." 13 Section 2 created "a liberal federal policy favoring arbitration agreements, notwithstanding any state substantive or procedural policies to the contrary." 14 The Act has proved influential. ${ }^{15}$

Although Congress passed the FAA in 1925, federal courts did not meaningfully address the arbitrability of antitrust claims until the 1960s. In 1968, the Second Circuit in American Safety Equipment Corp. v. J.P. Maguire \& $C o .{ }^{16}$ became the first court of appeals to hold that antitrust claims were not subject to arbitration. ${ }^{17}$ The Second Circuit articulated four reasons for concluding that the FAA did not apply to antitrust claims, which one scholar has summarized as:

(1) deference to private arbitration agreements could lessen the plaintiffs' incentive to pursue antitrust actions, weakening the use of "private attorneys general" as a foundation of Sherman Act enforcement; (2) arbitration clauses often result from adhesion contracts, and Congress intended that these matters be heard in the courts; (3) arbitrators may be incompetent to comprehend complex antitrust issues; and (4) arbitrators may be biased business people unable to reach fair outcomes. ${ }^{18}$

\footnotetext{
119 U.S.C. $\S \S 1-18$ (2012); In re Pharmacy Benefit Managers Antitrust Litig., 700 F.3d 109, 116 (3d Cir. 2012) ("Congress enacted the FAA in 1925 to counteract 'the traditional judicial hostility to the enforcement of arbitration agreements." (quoting Alexander v. Anthony Int'l, L.P., 341 F.3d 256, 263 (3d Cir. 2003))).

129 U.S.C. \& 2.

13 Gilmer v. Interstate/Johnson Lane Corp., 500 U.S. 20, 24 (1991).

14 Moses H. Cone Mem'l Hosp. v. Mercury Constr. Corp., 460 U.S. 1, 24 (1983).

15 John R. Allison, Arbitration Agreements and Antitrust Claims: The Need for Enhanced Accommodation of Conflicting Public Policies, 64 N.C. L. REV. 219, 227 (1986).

16391 F.2d 821 (2d Cir. 1968).

17 Id. at 826-28; Baker \& Stabile, supra note 4, at 402.

18 Steven R. Swanson, Antisuit Injunctions in Support of International Arbitration, 81 TUL. L. REV. 395, 409 (2006) (summarizing American Safety, 391 F.2d at 826-27); see also Nghiem v. NEC Elec., Inc., 25 F.3d 1437, 1441 (9th Cir. 1994) ("In American Safety, the Second Circuit held that antitrust claims cannot be arbitrated because of the public interest in enforcing antitrust laws, the potential bias and limited expertise of arbitrators, the complexity of antitrust law, and the procedural differences between trials and arbitrations."); Ramona L. Lampley, Is Arbitration Under Attack?: Exploring the Recent Judicial Skepticism of the Class Arbitration Waiver and Innovative Solutions to the Unsettled
} 
This rationale proved persuasive across the circuits, as courts relied on American Safety to hold that antitrust claims were not subject to arbitration. ${ }^{19}$ By the mid-1980s, the American Safety rule prohibiting arbitration of antitrust claims was well-established and not particularly controversial. ${ }^{20}$

\section{B. The Birth of Antitrust Arbitration and the Effective Vindication Doctrine}

The American Safety doctrine began to erode in the 1980s as the Supreme Court interpreted the FAA as creating a heavy presumption in favor of arbitration for all claims. ${ }^{21}$ The Supreme Court began to dislodge this wellentrenched rule when it considered whether Sherman Act claims could be decided by international arbitration tribunals in other countries. In Mitsubishi Motors Corp. v. Soler Chrysler-Plymouth, Inc., ${ }^{22}$ the Supreme Court held that an antitrust claim could be submitted to an international arbitral tribunal. ${ }^{23}$ Although the Mitsubishi Court claimed it was "unnecessary to assess the legitimacy of the American Safety doctrine as applied to agreements to arbitrate arising from domestic transactions," 24 the majority specifically dissected and rejected the Second Circuit's four rationales for making antitrust claims nonarbitrable. ${ }^{25}$ The Ninth Circuit treated the Mitsubishi "Court's meticulous step-by-step disembowelment of the American Safety doctrine" as "effectively overrul[ing] American Safety and its progeny." ${ }^{26}$ Other circuits followed suit and began to revisit their rules against allowing domestic antitrust claims to be arbitrated, ultimately holding that-despite the fact that Mitsubishi involved international

Legal Landscape, 18 CORNELL J.L. \& PUB. POL'Y 477, 518 (2009) (reciting the four rationales in another fashion).

19 See, e.g., Lake Commc'ns, Inc. v. ICC Corp., 738 F.2d 1473, 1479 (9th Cir. 1984); Lee v. Ply*Gem Indus., Inc., 593 F.2d 1266, 1274 (D.C. Cir. 1979); Applied Dig. Tech., Inc. v. Cont'1 Cas. Co., 576 F.2d 116, 117-19 (7th Cir. 1978); Cobb v. Lewis, 488 F.2d 41, 47 (5th Cir. 1974); Helfenbein v. Int'1 Indus., Inc., 438 F.2d 1068, 1070 (8th Cir. 1971).

${ }^{20}$ See Baker \& Stabile, supra note 4, at 403 ("Courts . . . continued to prohibit arbitration of antitrust claims for the next decade and a half [after American Safety].”).

${ }^{21}$ See Moses H. Cone Mem'l Hosp. v. Mercury Constr. Corp., 460 U.S. 1, 24-25 ("[Q]uestions of arbitrability must be addressed with a healthy regard for the federal policy favoring arbitration.... The Arbitration Act establishes that, as a matter of federal law, any doubts concerning the scope of arbitrable issues should be resolved in favor of arbitration, whether the problem at hand is the construction of the contract language itself or an allegation of waiver, delay, or a like defense to arbitrability.").

22473 U.S. 614 (1985).

${ }^{23}$ Id. at $632-35$.

${ }^{24} I d$. at 629 .

${ }^{25}$ Id. at 632-35 (expressing "skepticism of certain aspects of the American Safety doctrine"); see also Baker \& Stabile, supra note 4, at 406 ("Although the Court's holding in Mitsubishi is limited to the international arena, its logic is not.").

${ }^{26}$ Nghiem v. NEC Elec., Inc., 25 F.3d 1437, 1442 (9th Cir. 1994). 
arbitration - the opinion required that domestic antitrust lawsuits be subject to arbitration. ${ }^{27}$

In the aftermath of Mitsubishi, as a new consensus emerged that antitrust claims were arbitrable, federal courts employed the Effective Vindication Doctrine to ensure that the statutory rights of antitrust plaintiffs were still protected. In holding that international arbitration could supplant judicial adjudication of antitrust claims, the Mitsubishi Court reasoned that "so long as the prospective litigant effectively may vindicate its statutory cause of action in the arbitral forum, the statute will continue to serve both its remedial and deterrent function. ${ }^{28}$ If the antitrust plaintiff could not effectively vindicate its rights through arbitration, the arbitration agreement would be unenforceable and the plaintiff could pursue its antitrust claim in federal court. For example, the Mitsubishi majority "note[d] that in the event the choice-of-forum and choice-of-law clauses operated in tandem as a prospective waiver of a party's right to pursue statutory remedies for antitrust violations, we would have little hesitation in condemning the agreement as against public policy." 29 Antitrust arbitration was permissible because antitrust plaintiffs could effectively vindicate their rights in an alternative noncourt forum. The Effective Vindication Doctrine provides that "arbitration of the claim will not be compelled if the prospective litigant cannot effectively vindicate his statutory rights in the arbitral forum." ${ }^{30}$ The Eleventh Circuit has explained that "the arbitrability of [federal statutory]

27 See, e.g., Seacoast Motors of Salisbury, Inc. v. DaimlerChrysler Motors Corp., 271 F.3d 6, 11 (1st Cir. 2001) (expressly rejecting American Safety in view of Mitsubishi); Kotam Elecs., Inc. v. JBL Consumer Prods., Inc., 93 F.3d 724, 725-28 (11th Cir. 1996) (same); see also HCI Techs., Inc. v. Avaya, Inc., 446 F. Supp. 2d 518, 524 (E.D. Va. 2006) ("A review of subsequent case law reveals that while the grim reaper may not yet have found American Safety's address, he is certainly in the neighborhood."); Hunt v. Up N. Plastics, Inc., 980 F. Supp. 1046, 1049 (D. Minn. 1997) (“[T] he Supreme Court's decision[] in Mitsubishi Motors Corp. v. Soler Chrysler-Plymouth, Inc.... call[s] into question the rationale of earlier cases exempting antitrust ... claims from arbitration." (citation omitted)); Acquaire v. Can. Dry Bottling, 906 F. Supp. 819, 837 (E.D.N.Y. 1995) ("Since the Mitsubishi decision was issued, a number of district courts in this circuit have held that domestic antitrust disputes are arbitrable. I find no reason to conclude otherwise ...." (citations omitted)); Syscomm Int'l Corp. v. Synoptics Commc'ns, Inc., 856 F. Supp. 135, 139 (E.D.N.Y. 1994) ("While American Safety has not been explicitly overruled, this Court believes that . . domestic antitrust claims are arbitrable."); Hough v. Merrill Lynch, Pierce, Fenner \& Smith, Inc., 757 F. Supp. 283, 286 (S.D.N.Y. 1991) ("[T] he reasoning of Mitsubishi should apply with equal force to domestic claims."), aff'd, 946 F.2d 883 (2d Cir. 1991); W. Int'l Media Corp. v. Johnson, 754 F. Supp. 871, 873-74 (S.D. Fla. 1991) ("Although the Court supported its rejection of some of these concerns on grounds tied to the principles involved in international commercial transactions, the Court's reliance on arbitration principles and the legislative histories of antitrust provisions suggests that the result arrived at in Mitsubishi would be forthcoming in the domestic situation.").

28473 U.S. 614, 637 (1985).

${ }^{29} I d$. at 637 n. 19.

${ }^{30}$ In re Cotton Yarn Antitrust Litig., 505 F.3d 274, 282 (4th Cir. 2007) (citing Green Tree Fin. Corp.Ala. v. Randolph, 531 U.S. 79, 90 (2000)); see also Am. Express Co. v. Italian Colors Rest., 133 S. Ct. 2304, 2314 (2013) (Kagan, J., dissenting) ("An arbitration clause will not be enforced if it prevents the effective vindication of federal statutory rights, however it achieves that result."). 
claims rests on the assumption that the arbitration clause permits relief equivalent to court remedies. When an arbitration clause has provisions that defeat the remedial purpose of the statute, therefore, the arbitration clause is not enforceable." ${ }^{31}$ Justice Kagan has explained the importance of the Effective Vindication Doctrine:

The effective-vindication rule furthers the statute's goals by ensuring that arbitration remains a real, not faux, method of dispute resolution. With the rule, companies have good reason to adopt arbitral procedures that facilitate efficient and accurate handling of complaints. Without it, companies have every incentive to draft their agreements to extract backdoor waivers of statutory rights, making arbitration unavailable or pointless. ${ }^{32}$

Courts have treated the Effective Vindication Doctrine as a safeguard for allowing claims to be arbitrated. For example, in Green Tree Financial Corp.-Alabama v. Randolph, ${ }^{33}$ the Supreme Court recognized that "the existence of large arbitration costs could preclude a litigant... from effectively vindicating her federal statutory rights in the arbitral forum" but found that the plaintiff did not present sufficient evidence regarding such costs. ${ }^{34}$ If the evidence had been sufficient, the plaintiff could have evaded the arbitration clause and litigate in federal court. ${ }^{35}$

Before the Supreme Court decided Italian Colors, antitrust courts applied the Effective Vindication Doctrine to screen out and refuse to enforce arbitration clauses that did not provide an opportunity to effectively assert antitrust claims. For example, federal courts in antitrust litigation had relied on the doctrine to invalidate class action waivers contained in arbitration agreements ${ }^{36}$ and a provision that prohibited an arbitrator from

31 Paladino v. Avnet Comput. Techs., Inc., 134 F.3d 1054, 1062 (11th Cir. 1998) (citation omitted) (citing Gilmer v. Interstate/Johnson Lane Corp., 500 U.S. 20, 28 (1991)).

32 Italian Colors, 133 S. Ct. at 2315 (Kagan, J., dissenting).

33531 U.S. 79 (2000).

34 Id. at 90; see also Ellen Meriwether, Class Action Waiver and the Effective Vindication Doctrine at the Antitrust/Arbitration Crossroads, ANTITRUST, Summer 2012, at 67, 67 ("In ... Green Tree Financial Corp.-Alabama v. Randolph, the Supreme Court reinforced the principle that arbitration of federal statutory claims is appropriate where the plaintiffs' statutory rights can be effectively vindicated through arbitration ....”).

35 See Myriam Gilles \& Gary Friedman, After Class: Aggregate Litigation in the Wake of AT\&T Mobility v. Concepcion, 79 U. CHI. L. REV. 623, 634 (2012) (discussing Green Tree as placing the burden of proof on the party seeking to invalidate an antitrust arbitration agreement to show that "arbitration would be prohibitively expensive"); see also Myriam Gilles, Killing Them with Kindness: Examining "Consumer-Friendly" Arbitration Clauses After AT\&T Mobility v. Concepcion, 88 NOTRE DAME L. REV. 825, 832 (2012) ("Lower courts have been uniform in their recognition of the Green Tree test.").

36 Meriwether, supra note 34, at 69 ("Courts of appeals have followed similar logic in applying the effective vindication doctrine, focusing on cost and other practical considerations that affect whether arbitration is an effective means to vindicate rights under federal law. In some antitrust cases, courts have relied on the doctrine to invalidate class action waivers." (endnote omitted) (citing Kristian v. Comcast 
awarding treble damages. ${ }^{37}$ But the future contours (and existence) of the Effective Vindication Doctrine are now in doubt, as we explain in the following Section.

\section{Italian Colors and the Death of the Effective Vindication Doctrine}

In American Express Co. v. Italian Colors Restaurant, ${ }^{38}$ the Supreme Court revisited the Effective Vindication Doctrine after a group of merchants filed an antitrust class action against a credit card issuer. ${ }^{39}$ The merchants had entered contracts with American Express that contained arbitration clauses, which provided that " $[t]$ here shall be no right or authority for any Claims to be arbitrated on a class action basis." ${ }^{40}$ Despite signing these class action waivers, the merchants filed an antitrust class action in federal court. The merchants argued that because the necessary expert witnesses were so expensive, compelling the merchants to individually arbitrate would prevent them from effectively vindicating their rights to an antitrust remedy; a class action represented the only cost-effective form of adjudication. ${ }^{41}$

After the district court granted American Express's motion to dismiss based on the arbitration clause, the Second Circuit reversed, holding that "the plaintiffs have adequately demonstrated that the class action waiver provision at issue should not be enforced because enforcement of the clause would effectively preclude any action seeking to vindicate the statutory rights asserted by the plaintiffs." 42 The Supreme Court vacated the Second Circuit's decision without an opinion and remanded the case for further consideration in light of its opinion in Stolt-Nielsen S.A. v. AnimalFeeds International Corp,${ }^{43}$ which held that an arbitrator could not compel a party to submit to class-wide arbitration where the arbitration agreement was silent as to its availability. ${ }^{44}$ On remand, the Second Circuit declined a second time to enforce the class arbitration waiver. ${ }^{45}$ Shortly after that decision, the

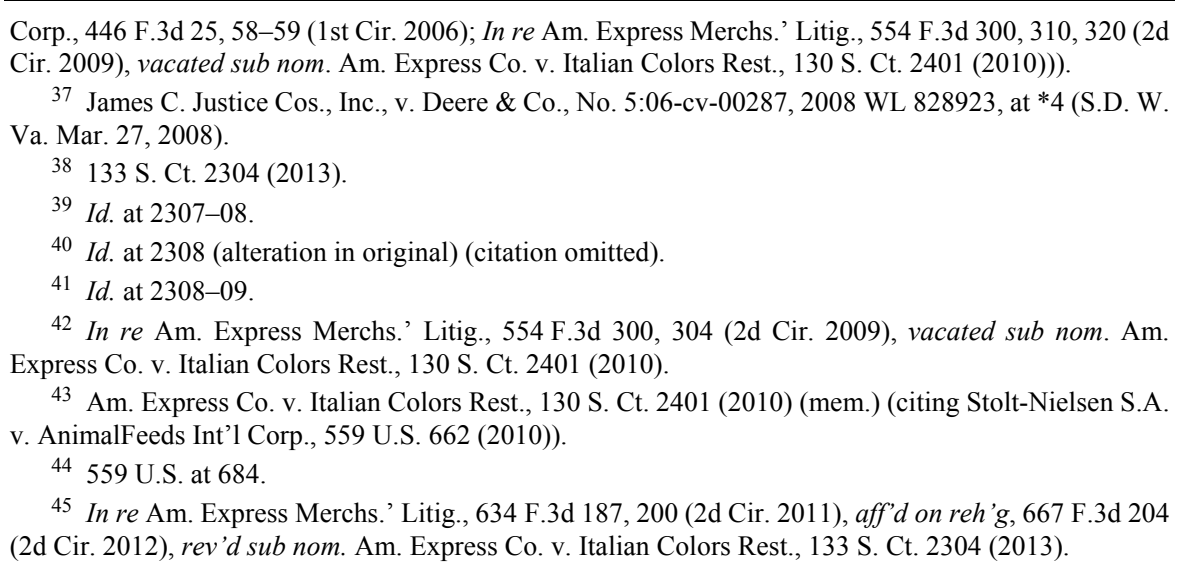


Supreme Court decided AT\&T Mobility LLC v. Concepcion,${ }^{46}$ holding that the FAA preempted California's rule against mandatory class arbitration waivers in consumer contracts, ${ }^{47}$ and the Second Circuit revisited its judgment. ${ }^{48}$ On reconsideration, the Second Circuit again held that the Effective Vindication Doctrine precluded mandatory individual arbitration of the merchants' claims. ${ }^{49}$ American Express appealed, and the Supreme Court granted certiorari for a second time..$^{50}$

The Supreme Court in Italian Colors again considered whether the Effective Vindication Doctrine excused the merchants from the mandatory arbitration clause and its class action waiver. Writing for the majority, Justice Scalia began by diminishing the Effective Vindication Doctrine as "dictum in Mitsubishi Motors, where we expressed a willingness to invalidate, on 'public policy' grounds, arbitration agreements that 'operat $[\mathrm{e}] \ldots$ as a prospective waiver of a party's right to pursue statutory remedies." '"51 While seeming to question the doctrine's pedigree, ${ }^{52}$ Justice Scalia converted it to a "willingness" of federal judges to protect plaintiffs instead of an obligation. ${ }^{53}$

Justice Scalia then applied the doctrine to the facts of Italian Colors. He noted the merchants' evidence "from an economist who estimated that the cost of an expert analysis necessary to prove the antitrust claims would be 'at least several hundred thousand dollars, and might exceed \$1 million,' while the maximum recovery for an individual plaintiff would be $\$ 12,850$, or $\$ 38,549$ when trebled. $"{ }^{4}$ Scalia asserted that what mattered was the right to pursue an antitrust remedy, not whether the merchants could exercise that right economically; he proclaimed that "the fact that it is not worth the

\footnotetext{
46 131 S. Ct. 1740 (2011).

${ }^{47}$ Id. at 1753. Although Concepcion seemed to reject the Effective Vindication Doctrine in context of state claims, the case "was decided on preemption grounds, ... and the Supreme Court had no occasion in that case to decide whether access to class proceedings was necessary for the effective vindication of a federal statutory right." Meriwether, supra note 34, at 67. Cf. Italian Colors, $133 \mathrm{~S}$. Ct. at 2319-20 (Kagan, J., dissenting) ("AT\&T Mobility was not-and could not have been-about the effectivevindication rule.").

48 In re Am. Express Merchs.' Litig., 667 F.3d 204, 206 (2d Cir. 2012), rev'd sub nom. Am. Express Co. v. Italian Colors Rest., 133 S. Ct. 2304 (2013)

${ }^{49} I d$. at 219-20.

50 Am. Express Co. v. Italian Colors Rest., 133 S. Ct. 594 (2012).

51 Italian Colors, $133 \mathrm{~S}$. Ct. at 2310 (alteration in original) (quoting Mitsubishi Motors Corp. v. Soler Chrysler-Plymouth, Inc., 473 U.S. 614, 637 n.19 (1985)). But see id. at 2317 (Kagan, J., dissenting) ("So whatever else the majority might think of the effective-vindication rule, it is not dictum.").

52 Justice Scalia admitted that "[s]ubsequent cases have similarly asserted the existence of an 'effective vindication' exception," but then noted that the Court "declined to apply it to invalidate the arbitration agreement at issue." Id. at 2310 (majority opinion) (citing 14 Penn Plaza LLC v. Pyett, 556 U.S. 247, 273-74 (2009); Gilmer v. Interstate/Johnson Lane Corp., 500 U.S. 20, 28 (1991)).

$53 \mathrm{Id}$.

${ }^{54} I d$. at 2308.
} 
expense involved in proving a statutory remedy does not constitute the elimination of the right to pursue that remedy." ${ }_{55}$ As applied, this meant that "a contractual waiver of class arbitration is enforceable under the Federal Arbitration Act when the plaintiff's cost of individually arbitrating a federal statutory claim exceeds the potential recovery." ${ }^{16}$ Consequently, the Court held that potential defendants can use arbitration clauses to prevent class actions ${ }^{57}$ even when a class action is the only way to effectively vindicate the right to an antitrust remedy because, according to Justice Scalia, "the antitrust laws do not guarantee an affordable procedural path to the vindication of every claim." 58

The majority opinion in Italian Colors effectively read the word "effective" out of the Effective Vindication Doctrine, turning it into what might be called the Nominal Vindication Doctrine. ${ }^{59}$ The antitrust plaintiffs in that case were precluded from suing in federal court even though the evidence established that they could not effectively vindicate their statutory rights through arbitration. Although the majority opinion suggested that the Effective Vindication Doctrine "would certainly cover a provision in an arbitration agreement forbidding the assertion of certain statutory rights" and "would perhaps cover filing and administrative fees attached to arbitration that are so high as to make access to the forum impracticable," 60 the Court never explained why an arbitration clause that rendered the individual plaintiffs' costs of arbitrating "so high as to make access to the forum impracticable" was not similarly violative of the Effective Vindication Doctrine. ${ }^{61}$

The Effective Vindication Doctrine has played an important role in preventing antitrust defendants from gutting the pro-plaintiff policies that have been the hallmarks of American antitrust law for over a century. But the holding and reasoning of Italian Colors suggest that that protection is over.

55 Id. at 2311.

${ }^{56} \mathrm{Id}$. at 2307.

${ }^{57}$ Id. at 2311 (discussing Gilmer, 500 U.S. at 32).

58 Id. at 2309.

59 See Mark Bolin, Fear and Loathing of Class Action Arbitration, or How to Dismiss the Effective Vindication Doctrine, 47 LOY. L.A. L. REV. 563 (2014) (making this argument).

60 Italian Colors, $133 \mathrm{~S}$. Ct. at 2310-11.

${ }^{61}$ See id. at 2317 (Kagan, J., dissenting) ("The majority is quite sure that the effective-vindication rule does not apply here, but has precious little to say about why."). 


\section{ANTITRUST ARBITRATION IN THE ABSENCE OF EFFECTIVE VINDICATION}

This Part considers the original concerns of the American Safety court, together with additional problems that may arise in antitrust arbitration in the wake of Italian Colors. Arbitration always entails procedural differences from traditional litigation, and these differences may as a practical matter implicate substantive rights. In theory, "[b]y agreeing to arbitrate a statutory claim, a party does not forgo the substantive rights afforded by the statute; it only submits to their resolution in an arbitral, rather than a judicial, forum." ${ }_{62}$ Nevertheless, scholars have long argued that "the antitrust plaintiff is deprived of important statutory rights in arbitration proceedings, such as the rights to treble damages, attorney fees, and liberal forum selection." 63

In the immediate post-Mitsubishi era, federal courts relied on the Effective Vindication Doctrine to thwart defendants' attempts to constrain antitrust law via arbitration clauses. ${ }^{64}$ With Italian Colors' weakening of the Effective Vindication Doctrine, potential antitrust defendants are more likely to use arbitration clauses to substantially reduce both the probability of antitrust liability and the amount of damages recovered by successful antitrust plaintiffs. Potential defendants are likely to strategically deploy arbitration clauses because, relative to traditional antitrust litigation, antitrust arbitration confers substantial advantages on defendants and imposes tremendous costs on plaintiffs. This Part examines the differences between arbitration and litigation, and shows that antitrust defendants have attempted to exploit these differences to prevent antitrust plaintiffs from effectively vindicating their rights.

\section{A. Procedural Differences}

Arbitration changes the procedures for adjudicating antitrust claims. Civil litigation in federal district courts is governed by extensive rules, including the Federal Rules of Civil Procedure, the Federal Rules of Evidence, and local court rules, as well as the judicial precedent interpreting all of these rules. ${ }^{65}$ Arbitration eliminates this intricate set of procedural

62 In re Cotton Yarn Antitrust Litig., 505 F.3d 274, 288 (4th Cir. 2007) (quoting Mitsubishi Motors Corp. v. Soler Chrysler-Plymouth, Inc., 473 U.S. 614, 628 (1985)).

63 Allison, supra note 15 , at 238.

64 See, e.g., James C. Justice Cos., v. Deere \& Co., No. 5:06-cv-00287, 2008 WL 828923, at *4 (S.D. W. Va. Mar. 27, 2008)

${ }^{65}$ Gregory G. Wrobel, We're Not in Kansas Anymore: Arbitrating Antitrust Claims, ANTITRUST, Fall 2004, at 5, 6 . 
protections. ${ }^{66}$ Although many commentators have praised "the relative informality and flexibility of the arbitral process" as more efficient than traditional antitrust litigation, ${ }^{67}$ this Section explains how this truncation of process - while facially more economical — can undermine the purposes of antitrust law and policy.

1. Discovery Limitations.-Arbitration limits discovery compared to traditional litigation. For example, arbitration does not generally use the full panoply of depositions, interrogatories, document requests, and motions to compel that are common in federal court. ${ }^{68}$ In particular, third-party discovery may be difficult or impossible depending on the circumstances. ${ }^{69}$ Although arbitrators can summon witnesses for the actual arbitration, ${ }^{70}$ prearbitration discovery from nonparty witnesses may not be possible, ${ }^{71}$ thus reducing the efficiency of the arbitration itself and making it harder for the parties to assess the strength of a case before trial. Such problems are particularly acute when dealing with international arbitration or foreign-

${ }^{66}$ Mitsubishi Motors, 473 U.S. at 657 n.31 (Stevens, J., dissenting); id. at 648 n.14 (“[T]he factfinding process in arbitration usually is not equivalent to judicial factfinding. The record of the arbitration proceedings is not as complete; the usual rules of evidence do not apply; and rights and procedures common to civil trials, such as discovery, compulsory process, cross-examination, and testimony under oath, are often severely limited or unavailable." (quoting Alexander v. Gardner-Denver Co., 415 U.S. 36, 57-58 (1974))).

${ }^{67}$ Loevinger, supra note 9, at 1089.

68 Charles E. Buffon \& Joshua D. Wolson, Antitrust Arbitration Counseling, ANTITRUST, Fall 2004, at 31, 32 ("For example, some arbitration rules do not permit depositions, but, instead, require witnesses to be called to a hearing before the arbitrator. Similarly, arbitration rules can be selected that do not allow document discovery that is as broad as that permitted under federal and state procedural rules ...."); Campbell et al., supra note 6, at 8 ("The procedural formalities of litigation-depositions, interrogatories, document requests, objections to discovery, motions to compel, motions to dismiss, third-party discovery, motions for summary judgment - are generally disfavored."); see also Myriam Gilles \& Anthony Sebok, Crowd-Classing Individual Arbitrations in a Post-Class Action Era, 63 DEPAUL L. REV. 447, 464 n.66 (2014) ("For example, the American Arbitration Association (AAA) Healthcare Payor Provider Arbitration Rules, which govern billing-related disputes, limit discovery to one deposition per party unless ordered by the arbitrator." (citation omitted)).

${ }^{69}$ Baker \& Stabile, supra note 4, at 410 ("Finally, the most significant and often discussed objection to arbitrating antitrust disputes concerns the difficulties in acquiring evidence from unwilling third parties. This barrier may prove virtually insuperable in many 'conspiracies with strangers' type antitrust disputes."); Elizabeth B. McCallum \& R. Mark McCareins, Arbitration Procedures: The Rules of the Road in Arbitrating Antitrust Disputes, ANTITRUST, Fall 2004, at 15, 18.

709 U.S.C. $\$ 7$ (2012).

71 McCallum \& McCareins, supra note 69, at 18 ("The circuits are split on whether the arbitrators have authority under the FAA to order third-party production of evidence before the arbitration hearing ...."); see, e.g., Integrity Ins. Co. v. Am. Centennial Ins. Co., 885 F. Supp. 69, $71-73$ (S.D.N.Y. 1995) (discussing and ultimately denying the power of arbitration contracts to compel nonparties to appear at prehearing depositions). 
based evidence, ${ }^{72}$ as foreign arbitrators sometimes do not have authority to secure witnesses or documents. ${ }^{73}$

Supporters of binding arbitration view this constriction of discovery as an advantage. Some commentators see these restrictions as an antidote for discovery run amok in antitrust litigation. ${ }^{74}$ Others have suggested that "[1]imited discovery often forces practitioners to narrow and sharpen their case earlier in the process than they might otherwise have done." 75 The Supreme Court has suggested that the diminished discovery is a reasonable cost for the "simplicity, informality, and expedition of arbitration." 76 This tradeoff may be of particular value to foreign defendants that are "troubled by the breadth and intrusiveness of American discovery." 77

While limited discovery reduces costs, it also makes it harder for plaintiffs to get necessary information from antitrust defendants. Discovery is often critical in antitrust litigation in a way that it is not in garden-variety commercial litigation, which generally turns on contract language and trade customs. In contrast, "the heart of any American antitrust case is the discovery of business documents. Without them, there is virtually no case." 78 In antitrust litigation, plaintiffs generally require more discovery than do defendants because "much of the information needed to prove that a monopolist is monopolizing is under the control of the monopolist." 79

72 Baker \& Stabile, supra note 4, at 411 ("The problem of third-party discovery in arbitration is generally more complex in the international context.").

73 E.g., Mitsubishi Motors Corp. v. Soler Chrysler-Plymouth, Inc., 473 U.S. 614, 657 n.31 (1985) (Stevens, J., dissenting) ("Japanese arbitrators do not have the power of compulsory process to secure witnesses and documents, nor do witnesses who are available testify under oath.”).

74 Allison, supra note 15, at 247. Allison has since pointed out that his argument applies to negotiated arbitration agreements and should not have been extended to contracts of adhesion. E-mail from John R. Allison, Mary John \& Ralph Spence Centennial Professor of Bus. Admin., McCombs Graduate Sch. of Bus., Univ. of Texas at Austin, to Mark Lemley, author (Mar. 24, 2015) (on file with authors).

75 McCallum \& McCareins, supra note 69, at 18.

76 Gilmer v. Interstate/Johnson Lane Corp., 500 U.S. 20, 31 (1991) (quoting Mitsubishi, 473 U.S., at 628). Lower courts are generally not sympathetic to arguments against arbitration based on limited discovery. See, e.g., In re Currency Conversion Fee Antitrust Litig., 265 F. Supp. 2d 385, 415 (S.D.N.Y. 2003).

77 Buffon \& Wolson, supra note 68 , at 31.

${ }^{78}$ In re Uranium Antitrust Litig., 480 F. Supp. 1138, 1155 (N.D. Ill. 1979) (quoting Timothy G. Smith, Note, Discovery of Documents Located Abroad in U.S. Antitrust Litigation: Recent Developments in the Law Concerning the Foreign Illegality Excuse for Non-Production, 14 Va. J. Int'1 L. 747, 747 (1974)); see also Baker \& Stabile, supra note 4, at 425 ("Adequate discovery often is key to the resolution of antitrust disputes.").

79 Margaret L. Moses, Statutory Misconstruction: How the Supreme Court Created a Federal Arbitration Law Never Enacted by Congress, 34 FlA. ST. U. L. REV. 99, 140 (2006) ("In arbitration, discovery is limited, making it much less likely that a victim of the monopoly will be able to establish his case and protect the rights Congress intended him to have."); see also Andrea Doneff, Is Green Tree v. Randolph Still Good Law? How the Supreme Court's Emphasis on Contract Language in Arbitration Clauses Will Impact the Use of Public Policy to Allow Parties to Vindicate Their Rights, 39 OHIO N.U. L. REV. 63, 65 (2012) ("In addition, arbitration's efficiencies often impact the party that can least afford 
Consequently, discovery restrictions asymmetrically benefit antitrust violators over their victims.

Antitrust defendants can withhold damning documents during arbitration and the antitrust plaintiff may have no meaningful recourse. For example, federal rules criminalizing perjury and spoliation of evidence do not generally apply to arbitration, ${ }^{80}$ which reduces deterrence of such abuses. Federal courts have reasoned that "[a]ny dispute over discovery would be procedural in nature, and therefore left for an arbitrator to resolve." ${ }^{81}$ Federal judges, for example, are generally deferential to arbiter decisions to reject plaintiffs' evidence requests. ${ }^{82}$ The Supreme Court has also proved itself unsympathetic to discovery-based arguments against arbitration..$^{83}$ Consequently, lower federal courts have held that limited discovery does not "raise[] a question of arbitrability." ${ }_{44}$

Arbitration could facilitate full discovery procedures if the parties agree to do so. ${ }^{85}$ Potential antitrust violators, however, are likely to structure arbitration clauses to limit discovery in any subsequent arbitration. And Concepcion and Italian Colors give them the ability to do so. ${ }^{86}$ Antitrust litigation often involves document asymmetry in that the defendant is rarely

the impact. Discovery may be significantly less broad in arbitration than in litigation. The party suing often has less information than the party being sued, so discovery can be key to a successful lawsuit.").

${ }^{80}$ Kristen M. Blankley, Taming the Wild West of Arbitration Ethics, 60 U. KAN. L. REV. 925, 928 29 (2012).

${ }^{81}$ Kristian v. Comcast Corp., 446 F.3d 25, 43 (1st Cir. 2006).

82 See Karaha Bodas Co. v. Perusahaan Pertambangan Minyak Dan Gas Bumi Negara, 364 F.3d 274, 301 (5th Cir. 2004) ("Every failure of an arbitrator to receive relevant evidence does not constitute misconduct requiring vacatur of an arbitrator's award." (quoting Hoteles Condado Beach, La Concha \& Convention Ctr. v. Union De Tronquistas Local 901, 763 F.2d 34, 40 (1st Cir. 1985))); Kellogg Brown \& Root Servs., Inc. v. Altanmia Commercial Mktg. Co., Civ. A. No. H-07-2684, 2007 WL 4190795, at *12 (S.D. Tex. Nov. 21, 2007) ("Arbitrators do have broad discretion to make decisions about what evidence they will accept and consider. Int'l Chem. Workers Union v. Columbia Chems. Co., 331 F.3d 491, 497 (5th Cir. 2003). It is not the role of the courts to dictate what evidence an arbitrator may consider in reaching his decision."); McCallum \& McCareins, supra note 69, at 17.

83 See AT\&T Mobility LLC v. Concepcion, 131 S. Ct. 1740, 1747 (2011); Gilmer v. Interstate/Johnson Lane Corp., 500 U.S. 20, 31 (1991).

${ }^{84}$ Kristian, 446 F.3d at $42-43$.

85 Baker \& Stabile, supra note 4, at 425 ("Parties can incorporate some or all discovery as permitted by the Federal Rules of Civil Procedure, although a higher showing of need may be required to govern pre-arbitration discovery."); McCallum \& McCareins, supra note 69, at 18 ("For instance, some agreements provide that the discovery procedures under the Federal Rules of Civil Procedure will apply."); see also Thomas J. Brewer, The Arbitrability of Antitrust Disputes: Freedom to Contract for an Alternative Forum, 66 ANTITRUST L.J. 91, 117-18 (1997) (describing various discovery procedure options parties can include in arbitration clauses, including "a requirement that 'good cause' must be shown in order to obtain leave to take a deposition, subjecting all discovery activities to a pre-agreed time limit, and, in three-arbitrator cases, agreeing that discovery disputes can be resolved by one arbitrator, typically the chair, rather than the entire panel").

${ }^{86}$ See, e.g., Arpan A. Sura \& Robert A. DeRise, Conceptualizing Concepcion: The Continuing Viability of Arbitration Regulations, 62 U. KAN. L. REV. 403, 462-63 (2013). 
going to need critical documents from the plaintiff while the plaintiff's case may turn on the smoking gun in the defendants' files. In contrast to arbitration, litigation does not give defendants the input-input that sometimes amounts to veto power-over the discovery process that arbitration does.

2. Arbitrator Qualifications and Bias.-The processes by which arbitral tribunals are constituted may result in arbitrators who are either unqualified to decide antitrust disputes, biased, or both. These risks are independent but can operate in tandem. In this Section we discuss each separately.

Arbitrator competence is not a new concern; the Second Circuit in American Safety worried that commercial arbitrators may not have sufficient experience or qualifications to decide antitrust issues. ${ }^{87}$ Traditionally, arbitrators were often industry experts, not lawyers or judges. ${ }^{88}$ When an antitrust claim is part of a broader lawsuit, courts have expressed concern that arbitrators may be selected for the knowledge of other relevant areas of law or trade custom, and consequently "ill-equipped to interpret the antitrust laws." 89

In theory, knowledgeable arbitrators, including one or more with antitrust experience, may be available to decide complex antitrust cases..$^{90}$ Ideally, the parties can select an arbitrator with both a sophisticated legal background and an understanding of the relevant industry. ${ }^{91}$ The defendant that recognizes its conduct has crossed the line, however, has every incentive to keep arbitrators who understand antitrust law off of the panel. For example, in one infamous older case, the antitrust defendant rejected as arbitrators every lawyer with antitrust knowledge and approved only businesspeople and money lenders, despite the novelty and complexity of

87 391 F.2d 821, 827 (2d Cir. 1968) ("[I]t is the business community generally that is regulated by the antitrust laws. Since commercial arbitrators are frequently men drawn for their business expertise, it hardly seems proper for them to determine these issues of great public interest. ... We express no general distrust of arbitrators or arbitration ....").

88 Loevinger, supra note 9, at 1090 ("Arbitrators are likely to be businessmen who are knowledgeable in the trade but not qualified to pass judgment on antitrust claims."); see also Mitsubishi Motors Corp. v. Soler Chrysler-Plymouth, Inc., 473 U.S. 614, 654 n.23 (1985) (Stevens, J., dissenting) ("Federal antitrust issues . . . are considered to be at once too difficult to be decided competently by arbitrators - who are not judges, and often not even lawyers - and too important to be decided otherwise than by competent tribunals." (citation omitted)).

89 Associated Milk Dealers, Inc., v. Milk Drivers Union, Local 753, 422 F.2d 546, 552 (7th Cir. 1970) ("Arbitrators are ill-equipped to interpret the antitrust laws and their consideration of possible violations would add little.").

90 McCallum \& McCareins, supra note 69, at 17. See, e.g., Baker \& Stabile, supra note 4, at 418 (noting a case where the arbitrator was Thomas E. Kauper, an antitrust professor at the University of Michigan School of Law and former Assistant Attorney General).

91 Buffon \& Wolson, supra note 68, at 32. 
the antitrust issues involved. ${ }^{92}$ In the American Safety era, Judge Posner once explained that antitrust issues were not arbitrable because "[ $[\mathrm{t}]$ hey are considered to be at once too difficult to be decided competently by arbitrators - who are not judges, and often not even lawyers - and too important to be decided otherwise than by competent tribunals. ${ }^{93}$

Even if an arbitrator is sufficiently experienced to understand an antitrust claim, the prospect of bias can undermine faith in the process. Structural features common to antitrust arbitration also raise a substantial possibility that an arbitrator will be biased. Traditional accounts of arbitration's advantages do not account for this possibility because they envision commercial arbitration as between two businesses, often participants in the same industry. In those circumstances, there is less risk of the arbitrator having an industry bias that systematically favors plaintiffs over defendants or vice versa because both parties and the arbitrator are members of the same business community. Antitrust disputes, by contrast, often involve consumers suing dominant firms. Selecting arbitrators from the business community in such scenarios creates the possibility of weakened antitrust scrutiny against defendants. ${ }^{94}$ The reality of arbitrator bias came in to stark relief in 2009 when the Minnesota Attorney General's Office sued the National Arbitration Forum (NAF) - the then-leading debt collection arbitration forum - for fraud because of its hidden financial ties to the debt collection industry ${ }^{95}$ Within days after the suit was filed, the NAF settled by agreeing to stop arbitrating consumer debt collection claims. ${ }^{96}$

Even absent outright deception, such as that engaged in by the NAF, repeat-player bias may infect the arbitration process. ${ }^{97}$ Defendants— but not

92 John J. Finn, Private Arbitration and Antitrust Enforcement: A Conflict of Policies, 10 B.C. INDUS. \& Com. L. Rev. 406, 412-13 (1969) (discussing Aimcee Wholesale Corp. v. Tomar Prods., Inc., 237 N.E.2d 223 (N.Y. 1968)).

93 Univ. Life Ins. Co. of Am. v. Unimarc Ltd., 699 F.2d 846, 851 (7th Cir. 1983).

94 See Finn, supra note 92, at 414 ("'[B]ecause of the natural wariness of industry in general toward antitrust restrictions, the tendency would in all probability run in the direction of weakening antitrust standards."); Loevinger, supra note 9, at 1090 ("Antitrust law is a code for restraining business conduct. Consequently those who are likely to be chosen as arbitrators are not likely to be sympathetic to antitrust rules. In any event, the tenure of arbitrators does not give them the independence of judges; they are more apt to seek results which are acceptable to the parties than to insist upon decisions which may be socially desirable but unfavorable to the parties.").

95 Fed. Trade Comm'N, Repairing A Broken SyStem 39 (2010), https://www.ftc.gov/sites/default/files/documents/reports/federal-trade-commission-bureau-consumerprotection-staff-report-repairing-broken-system-protecting/debtcollectionreport.pdf [perma.cc/WEK39LRD]; Jessica Silver-Greenberg \& Michael Corkery, In Arbitration, a 'Privatization of the Justice System, ' N.Y. TIMES, Nov. 2, 2015, at A1 (noting that arbitrators have a pro-business bias).

96 Id. at 39-40. See also Consent Judgment, Minnesota v. Nat'l Arbitration Forum, Inc., 27-CV-0918550 (Minn. Dist. Ct. July 17, 2009), http://pubcit.typepad.com/files/nafconsentdecree.pdf [http://perma.cc/YV63-6UHX].

97 Fed. TRAde COMM'N, supra note 95, at 48. 
plaintiffs - are likely to be repeat players in consumer antitrust arbitrations..$^{98}$ Some scholars have speculated "that arbitrators often answer for their ongoing business to the party being sued - the large corporation that places an arbitration clause in all its contracts becomes a repeat customer that ends up keeping the arbitrator in business - and therefore become biased in favor of the corporation." " Courts have noted that arbitration favors corporate defendants because "[s]everal studies have found and several courts have held that a party's repeated appearance 'before the same group of arbitrators conveys distinct advantages over the [one-time participant]." 100 This has been shown to be a problem in other areas of law where one side is a repeat player, including employment law, ${ }^{101}$ securities arbitrations, ${ }^{102}$ and the ICANN trademark dispute resolution process. ${ }^{103}$ If the market for arbitrators favors those arbitrators most likely to rule for an antitrust defendant - and the structure of the market for arbitrators suggests that it does ${ }^{104}$-then arbitrators may have either an overt or unconscious bias to view evidence in a positive light toward the defense in antitrust cases. ${ }^{105}$ Furthermore, some

98 In practice, the fact that a relatively small group of plaintiff's antitrust lawyers are repeat players, even if their clients are not, may mitigate this risk somewhat.

99 Doneff, supra note 79, at 65 (citing Nancy A. Welsh, What Is “(Im)Partial Enough” in a World of Embedded Neutrals?, 52 ARIZ. L. REV. 395 (2010)); see also Stavros Brekoulakis, Systemic Bias and the Institution of International Arbitration: A New Approach to Arbitral Decision-Making, 4 J. INT'L DISP. SETTLEMENT 553 (2013) (identifying sources of systemic bias in arbitration); Andrew T. Guzman, Arbitrator Liability: Reconciling Arbitration and Mandatory Rules, 49 DuKE L.J. 1279, 1303 (2000) (arguing that reputational concerns will cause arbitrators to honor arbitration agreements over mandatory rules).

100 Schnuerle v. Insight Commc'ns Co., 376 S.W.3d 561, 579 (Ky. 2012) (second alteration in original) (quoting Mercuro v. Superior Court, 116 Cal. Rptr. 2d 671, 678 (Cal. Ct. App. 2002)); see also FED. TRADE COMM'N, supra note 95, at 48-49 (reviewing a study that found that "arbitrators who decided in favor of firms, as opposed to consumers, subsequently received more matters from the arbitration forum").

101 See, e.g., Alexander J.S. Colvin, An Empirical Study of Employment Arbitration: Case Outcomes and Processes, 8 J. EMPIRICAL LEGAL STUD. 1, 1 (2011) (finding "a significant repeat-employerarbitrator pairing effect in which employees on average have lower win rates and receive smaller damage awards where the same arbitrator is involved in more than one case with the same employer").

102 See, e.g., Steven A. Ramirez, Arbitration and Reform in Private Securities Litigation: Dealing with the Meritorious as Well as the Frivolous, 40 WM. \& MARY L. REV. 1055, 1110-11 (1999) (advocating securities arbitrations take place "under the auspices of the SEC" to mitigate against any potential pro-industry bias).

103 See, e.g., Elizabeth G. Thornberg, Fast, Cheap, and Out of Control: Lessons from the ICANN Dispute Resolution Process, 6 COMPUTER L. REV. \& TECH. J. 89, 121 (2002) ("[A] subtler kind of direct bias may arise from the volume of business that a repeat player can bestow.").

104 Kelsey J. Dolven, Comment, David Versus Two Goliaths: Why the Wisconsin State Legislature Needs to Update the Wisconsin Consumer Act by Placing Restrictions on Mandatory Arbitration, 2014 WIS. L. REV. 139, 142 ("Arbitrators compete to be selected by the parties, work under short-term contracts, and may fear a loss of future work if their decisions are seen as unfavorable to the parties that are most likely to appear in subsequent arbitrations.").

105 See generally Christopher R. Leslie, Rationality Analysis in Antitrust, 158 U. PA. L. REV. 261, 308-18 (2010) (discussing cognitive bias). 
arbitrators may not apply U.S. antitrust law as defined by binding federal precedent, potentially weakening another constraint on biased decisionmaking. ${ }^{106}$

In sum, problems of competence and bias ensue when arbitrators are chosen for their business knowledge, not their familiarity with the complexities of antitrust law. ${ }^{107}$ Indeed, antitrust law is more complicated now than when the Second Circuit rendered antitrust claims nonarbitrable in American Safety. ${ }^{108}$

To be sure, no system of adjudication is perfect. Judges and juries will not necessarily be familiar with antitrust law either. And individual judges or juries may be biased in particular cases. But judges and juries are at least required to apply the law, and any biases are likely to be idiosyncratic, not systematic.

This risk of consumers being forced to have their antitrust claims decided by an arbitrator who is either unqualified or biased is ever present. This danger is amplified by the fact that a losing consumer's ability to appeal an adverse arbitration ruling is severely limited, as the following Section explains.

3. Limited Appeals.-The powers of arbitrators - and the costs of their mistakes - are magnified by the lack of meaningful review. Although federal judicial review of arbitration decisions and awards is theoretically possible, the bases for vacating an arbitral award under the FAA are essentially limited to awards secured through corruption, fraud, and undue means. ${ }^{109}$ An

106 Guzman, supra note 99, at 1306 ("In one survey, albeit somewhat dated, 90\% of the arbitrators surveyed felt that "they were free to ignore these rules [of substantive law] whenever they thought that more just decisions would be reached by doing so." (alteration in original) (quoting Soia Mentschikoff, Commercial Arbitration, 61 ColuM. L. REV. 846, 861 (1961))); id. at 1297 (criticizing Mitsubishi because "there is no guarantee that the arbitrators will, in fact, apply U.S. antitrust laws to the dispute"); id. at 1306 ("Even judges have recognized that arbitrators are willing to ignore substantive legal rules." (citing Wilko v. Swan, 201 F.2d 439 (2d Cir.), rev'd, 346 U.S. 427 (1953))).

107 Loevinger, supra note 9, at 1088 ("Arbitrators are often businessmen chosen for their familiarity with the practices of a particular industry or their expertise with the issues in dispute. Most arbitrators would be unfamiliar with antitrust problems."); $i d$. at 1090 ("Antitrust issues are usually complicated, extensive and diverse and involve specialized legal claims and rules. The length and complexity of antitrust trials is a matter of common knowledge among lawyers, and the specialized and technical nature of antitrust principles is a matter of common and unfavorable comment among businessmen."); Robert Pitofsky, Arbitration and Antitrust Enforcement, 44 N.Y.U. L. REV. 1072, 1077-78 (1969) ("Another problem arises if the arbitrator, consistent with current practices, is a businessman chosen for his familiarity with the details of the industry in which the controversy arises. Most antitrust issues are too technical and complex to be disposed of by untrained personnel.").

108 Fewer claims are subject to per se treatment now than in the 1960s. See Maurice E. Stucke, Morality and Antitrust, 2006 CoLUM. BuS. L. REV. 443, 529 ("Since the 1980s, antitrust's per se liability standard is being applied to fewer practices.").

1099 U.S.C. $\S 10($ a) (2012). See Campbell et al., supra note 6, at 12. 
arbitrator's getting the law wrong is not grounds for appeal. ${ }^{110}$ Review by federal judges is not merely deferential; it is often nonexistent. ${ }^{111}$ There is no effective mechanism to correct most types of mistakes, even when those mistakes are dispositive. ${ }^{112}$ Because arbitrators are generally not required to issue written opinions or to explain their reasoning, they often do not. ${ }^{113}$ The absence of an adequate record means that in many cases "the arbitrator's decision is virtually unreviewable." 114 Even when a record exists, federal courts do not generally review an arbitrator's findings of fact and conclusions of law. ${ }^{115}$ The lack of a full appeals process is also troubling because an arbitrator can grant the equivalent of summary judgment, which means that an antitrust plaintiff can lose without a full hearing and without any recourse. ${ }^{116}$

As a result, arbitrators can get the law wrong and the losing party can still be without recourse. ${ }^{117}$ Because courts are bound to enforce arbitration decisions "absent extremely limited circumstances," even incorrect decisions will very likely be "final and effectively unappealable." 118 Writing in the context of foreign arbitration panels, the Supreme Court has noted that "[a]n arbitral award can be made without explication of reasons and without development of a record, so that the arbitrator's conception of our statutory

\footnotetext{
110 Buffon \& Wolson, supra note 68, at 33.

111 McCallum \& McCareins, supra note 69, at 21 ("[T]he arbitrator's " "improvident, even silly, factfinding" does not provide a basis for a reviewing court to refuse to enforce the award." (endnote omitted)). But see Eric James Fuglsang, Comment, The Arbitrability of Domestic Antitrust Disputes: Where Does the Law Stand?, 46 DEPAUL L. REV. 779, 809 n.264 (1997) (collecting cases where federal courts overturned arbitrator decisions).

112 Finn, supra note 92, at 413 ("“I]t is important to note that the opportunity for correction of errors is very limited. In a court proceeding errors of law are open to close scrutiny and correction on appeal. On the other hand, the decisions of arbitrators are essentially final and binding." (citing Wilko v. Swan, 346 U.S. 427, 436-37 (1953); James Richardson \& Sons v. W.E. Hedger Transp. Corp., 98 F.2d 55, 57 (2d Cir. 1938))). This includes incorrect findings of antitrust liability. See Mitsubishi Motors Corp. v. Soler Chrysler-Plymouth, Inc., 473 U.S. 614, 657 n.32 (1985) (Stevens, J., dissenting) (“The greatest risk, of course, is that the arbitrator will condemn business practices under the antitrust laws that are efficient in a free competitive market. In the absence of a reviewable record, a reviewing district court would not be able to undo the damage wrought." (citation omitted)).

113 Sarah Rudolph Cole, The Federalization of Consumer Arbitration: Possible Solutions, 2013 U. CHI. LEGAL F. 271, 294 (2013); see also id. at $297 \mathrm{n} .108$ (citing cases confirming that arbitrators are under no obligation to write opinions). Some arbitration organizations allow consumers to request a written decision that reflects the arbitrator's reasoning and award. See id. at 299-300. This is in flux, as some dispute resolution organizations have moved toward encouraging an opinion of some sort. $I d$. at 302 .

114 Mitsubishi, 473 U.S. at 656-57 (Stevens, J., dissenting).

115 McCallum \& McCareins, supra note 69, at 21.

116 See id. at 19.

117 Loevinger, supra note 9, at 1087 ("Arbitrators are not bound by rules of law; their decisions are essentially final and cannot be set aside for misapplication of the law.").

118 Buffon \& Wolson, supra note 68, at 33.
} 
requirement may be absolutely incorrect yet functionally unreviewable, even when the arbitrator seeks to apply our law." 119 Thus, while an arbitrator's "manifest disregard" of the law may theoretically provide a basis for reversal, ${ }^{120}$ this will be difficult to prove in the absence of a full record or an opinion, especially when federal courts are so deferential to private arbitrators. ${ }^{121}$

\section{B. Arbitration and Antitrust Remedies}

Many arbitration clauses attempt to do much more than merely provide an alternative decisionmaker to take the place of a federal judge. Although arbitration is not supposed to affect substantive antitrust law, ${ }^{122}$ many clauses explicitly limit remedies, forbid fee shifting, and truncate statutes of limitations. This creates a problem given that the Supreme Court has held that the FAA "requires courts to enforce agreements to arbitrate according to their terms." 123 This Section illustrates defendants' efforts to evade the proplaintiff aspects of statutory antitrust law.

1. Treble Damages.-The successful private antitrust plaintiff is entitled to treble damages. ${ }^{124}$ The trebling is mandatory; the judge exercises no discretion. ${ }^{125}$ This provision for mandatory treble damages was unique when adopted, ${ }^{126}$ highlighting the importance that Congress attached to private antitrust actions.

The automatic trebling of antitrust damages serves three related purposes. First, increasing damages enhances deterrence. The Supreme Court has noted that " $[\mathrm{t}]$ he treble-damages provision wielded by the private litigant is a chief tool in the antitrust enforcement scheme, posing a crucial

\footnotetext{
119 Scherk v. Alberto-Culver Co., 417 U.S. 506, 532 (1974).

120 Anjanette H. Raymond, It Is Time the Law Begins to Protect Consumers from Significantly OneSided Arbitration Clauses Within Contracts of Adhesion, 91 NEB. L. REV. 666, 691 (2013).

121 This lack of a meaningful appeals process is particularly frustrating because the legislative history of the Federal Arbitration Act suggests that the 1925 Congress believed that the party that lost at arbitration would have a meaningful right to appeal in court. See Arbitration of Interstate Commercial Disputes: Joint Hearings on S. 1005 and H.R. 646 Before the Subcomm. of the Comm. on the Judiciary, 68th Cong. 36-37 (1924).

122 Mitsubishi Motors Corp. v. Soler Chrysler-Plymouth, Inc., 473 U.S. 614, 628 (1985).

123 CompuCredit Corp. v. Greenwood, 132 S. Ct. 665, 669 (2012).

124 15 U.S.C. $\S 15$ (a) (2012)

125 Kristian v. Comcast Corp., 446 F.3d 25, 47 (1st Cir. 2006) (“15 U.S.C. § 15(a) states in relevant part that a private antitrust plaintiff 'shall recover threefold the damages by him sustained.' (emphasis added) Congress's use of the word 'shall' makes the treble damages remedy a mandatory result if a plaintiff successfully sues an antitrust violator.”). Statutory exemptions to mandatory trebling exist, but are not relevant to our analysis.

${ }^{126}$ Mitsubishi, 473 U.S. at 653 (Stevens, J., dissenting).
} 
deterrent to potential violators." 227 While triple actual damages may seem like a penalty to the defendant and a windfall to plaintiffs, the fact that antitrust violations are clandestine, ${ }^{128}$ and thus hard to detect, means that awarding only actual damages would allow many defendants to get away with violating the law and encourage others to make a rational choice to violate the law and risk nothing worse than giving up their gains from illegal behavior. ${ }^{129}$

In addition to deterrence, a second major purpose of the treble damage remedy is "to compensate victims of antitrust violations for their injuries." 130 The Court has often described trebling as serving an essential remedial purpose. ${ }^{131}$ And because antitrust violations can take many years to discover and many more - even decades - to litigate, ${ }^{132}$ an increase in damages is necessary to compensate for the interest lost during the period of overcharge. ${ }^{133}$

${ }^{127}$ Id. at 635 (majority opinion) (citing Perma Life Mufflers, Inc. v. Int'l Parts Corp., 392 U.S. 134, 138-39 (1968)); see also Donald I. Baker, Revisiting History-What Have We Learned About Private Antitrust Enforcement That We Would Recommend to Others?, 16 LOY. CONSUMER L. REV. 379, 382 (2004) ("The core, modern rationale for treble damages must be deterrence."). To be sure, optimal deterrence is not perfect deterrence. See Michael K. Block \& J. Gregory Sidak, The Costs of Deterrence: Why Not Hang a Price Fixer Now and Then?, 68 GEO. L.J. 1131 (1980) (arguing for optimal deterrence and noting that such a policy will not deter all antitrust violations). The antitrust laws settled on treble damages as a compromise between under- and overdeterrence of antitrust violations. See Howard A. Shelanski, The Case for Rebalancing Antitrust and Regulation, 109 MICH. L. REV. 683, 711 (2011).

128 Christopher R. Leslie, Cartels, Agency Costs, and Finding Virtue in Faithless Agents, 49 WM. \& MARY L. REV. 1621, 1634 (2008).

129 Christopher R. Leslie, De Facto Detrebling: The Rush to Settlement in Antitrust Class Action Litigation, 50 ARIZ. L. REV. 1009, 1039 (2008) (“As long as a firm enjoys a non-negligible chance of evading responsibility, violating antitrust laws appears rational: if not caught, the firm secures illegal profits, and, if caught, it simply returns the ill-gotten gains."); see also Joshua P. Davis \& Robert H. Lande, Toward an Empirical and Theoretical Assessment of Private Antitrust Enforcement, 36 SEATTLE U. L. REV. 1269 (2013) (arguing that private antitrust actions serve a substantial compensatory and deterrent purpose); Robert H. Lande, Are Antitrust "Treble" Damages Really Single Damages?, 54 OHIO ST. L.J. 115 (1993) (arguing that various factors render treble damages less than a true tripling of actual damages); John M. Connor \& Robert H. Lande, Not Treble Damages: Cartel Recoveries Are Mostly Less than Single Damages, 100 Iowa L. REV. 1997 (2015).

130 Ill. Brick Co. v. Illinois, 431 U.S. 720, 746 (1977).

131 E.g., Mitsubishi, 473 U.S. at 635-36 ("Notwithstanding its important incidental policing function, the treble-damages cause of action conferred on private parties by $\S 4$ of the Clayton Act ... seeks primarily to enable an injured competitor to gain compensation for that injury." (citation omitted)).

132 See, e.g., John M. ConNor, Global PRICE FIXING 349 (2d ed. 2008) (describing a Department of Justice investigation and prosecution lasting over six years); Richard A. Posner, A Statistical Study of Antitrust Enforcement, 13 J.L. \& ECON. 365, 381 (1970) (finding the average duration of antitrust cases to be over twenty months).

133 Unlike other areas, such as patent law, antitrust does not provide for awards of prejudgment interest. Fishman v. Estate of Wirtz, 807 F.2d 520, 582-83 (7th Cir. 1986) (Easterbrook, J., dissenting). 
The third purpose of treble damages is to "encourage private enforcement of the antitrust laws." 134 Government enforcement might punish past violations and prohibit illegal conduct in the future, but it cannot compensate customers for overcharges or the loss of competition. And government enforcers may not have the motivation or the resources to enforce the antitrust laws optimally, particularly if the defendants are politically powerful. ${ }^{135}$ By ensuring a substantial payoff for successful antitrust claims, mandatory treble damages create "a special incentive" for private actors to challenge antitrust violators. ${ }^{136}$ As the Supreme Court has recognized, Congress provided "the antitrust treble-damages provision [to] give[] private parties an incentive to bring civil suits that serve to advance the national interest in a competitive economy."137

Treble damages, in short, serve triple duty.

Despite - or perhaps because of - the multiple purposes served by antitrust law's trebling provision, potential antitrust defendants have sought to detreble antitrust damages through arbitration. In drafting mandatory arbitration clauses, potential antitrust defendants often try to nullify the Sherman Act's treble damage provision. ${ }^{138}$ For example, an arbitration clause imposed by Comcast provided:

IN NO EVENT SHALL WE OR OUR EMPLOYEES OR AGENTS HAVE ANY LIABILITY FOR PUNITIVE, TREBLE, EXEMPLARY, SPECIAL, INDIRECT, INCIDENTAL OR CONSEQUENTIAL DAMAGES. ... SUCH LIMITATION OF LIABILITY APPLIES IN ALL CIRCUMSTANCES, REGARDLESS OF WHETHER SUCH DAMAGES MAY BE AVAILABLE UNDER APPLICABLE LAW, AND THE PARTIES HEREBY WAIVE THEIR RIGHTS, IF ANY, TO RECOVER ANY SUCH DAMAGES. ${ }^{139}$

This represents an explicit effort to circumvent statutory law. Antitrust practitioners are sometimes encouraged to consider using arbitration

134 Pollock \& Riley, Inc. v. Pearl Brewing Co., 498 F.2d 1240, 1242-43 (5th Cir. 1974) (citing Bruce's Juices, Inc. v. Am. Can Co., 330 U.S. 743, 751-52 (1947)).

135 See generally Steven C. Salop, What Consensus? Why Ideology and Elections Still Matter to Antitrust, 79 ANTITRUST L.J. 601 (2014).

136 Mitsubishi, 473 U.S. at 653 (Stevens, J., dissenting).

137 Shearson/Am. Exp. Inc. v. McMahon, 482 U.S. 220, 241 (1987). See also Baker \& Stabile, supra note 4, at 397 ("Because it distrusted the government's ability and willingness to enforce the new law vigorously, Congress established at the outset a unique bounty-hunting scheme to encourage private parties to enforce the Sherman Act themselves. Thus, the successful plaintiff would get treble damages for any loss proven, as well as reasonable lawyers' fees and costs.").

138 See, e.g., James C. Justice Cos., Inc. v. Deere \& Co., No. 5:06-cv-00287, 2008 WL 828923, at*4 (S.D. W. Va. Mar. 27, 2008) ("The Dealership Agreement prevents the recovery of 'multiple damage' and states that 'each party shall bear its costs associated with the arbitration, including attorneys' fees[.]"' (alteration in original)).

139 Kristian v. Comcast Corp., 446 F.3d 25, 44 (1st Cir. 2006) (ellipsis in original). 
provisions to help their clients evade antitrust law's mandatory treble damages. ${ }^{140}$ The next question, for our purposes, is whether these provisions are enforceable.

An arbitrator's power to ignore antitrust law's dictate of treble damages is unclear. The Supreme Court has not directly held that parties cannot contractually waive the trebling provision of antitrust law. ${ }^{141}$ The Court has, however, held that when an arbitration clause is ambiguous as to whether it limits the automatic trebling provision of the relevant statute, the case must proceed to arbitration - not federal court - to interpret the reach and effect of the clause on the availability of that remedy. ${ }^{142}$ In PacifiCare Health Systems, Inc. v. Book, the Supreme Court declined to decide whether an arbitration agreement could bar a civil RICO plaintiff from seeking the treble damages authorized by that statute, ${ }^{143}$ holding "that the arbitrators - not the court - should decide in the first instance whether a particular arbitration agreement impermissibly limits statutory treble damages if the agreement at issue is ambiguous." 144 As a result, abstruse remedies limitations in an arbitration agreement proceed to the arbitral forum and not federal court. ${ }^{145}$ This creates the opportunity for arbitrators to make an unreviewable determination that an arbitration clause precludes trebling, and consequently award a successful antitrust plaintiff single — not trebled - damages.

In the absence of clear Supreme Court precedent on the waivability of treble damages, the decisions of the lower federal courts have been equivocal. One class of cases has noted that "[p]rovisions in arbitration

\footnotetext{
140 Brewer, supra note 85, at 119 ("Parties also might consider providing that a successful antitrust claimant cannot recover treble damages or recover its attorney's fees and litigation costs, notwithstanding the provisions of 15 U.S.C. $\S 15$ (a)." (footnote omitted)).

141 Kristian, 446 F.3d at 47 ("There is no Supreme Court precedent that speaks directly to the question of whether treble damages under federal antitrust law may be waived by contract.").

142 PacifiCare Health Sys., Inc. v. Book, 538 U.S. 401, 407 n.2 (2003) ("Given our presumption in favor of arbitration, Moses H. Cone Memorial Hospital v. Mercury Constr. Corp., 460 U.S. 1, 24-25 (1983), we think the preliminary question whether the remedial limitations at issue here prohibit an award of RICO treble damages is not a question of arbitrability.").

143 RICO also has a statutory treble damages provision. 18 U.S.C. § 1964(c) (2012).

144 McCallum \& McCareins, supra note 69, at 21.

145 Kristian, 446 F.3d at 45 ("[W]hen there is ambiguity about the scope of a remedies limitation of an arbitration agreement, the arbitrator will decide the question of enforceability in the first instance." (citing PacifiCare, 538 U.S. at 407)); In re Universal Serv. Fund Tel. Billing Practices Litig., 300 F. Supp. 2d 1107, 1127 (D. Kan. 2003) ("[T]he extent to which the limitation of liability on punitive or exemplary damages actually bans a treble damage award on plaintiffs' antitrust claim is disputable. Therefore, that issue must first be resolved by the arbitrator."); see also Estate of Parsons v. Palestinian Auth., 651 F.3d 118, 149 n.9 (D.C. Cir. 2011) (interpreting PacifiCare as holding that "the arbitrator [decides] the question whether an arbitration agreement which precluded punitive damages also barred treble damages under RICO”).
} 
agreements that prohibit punitive damages are generally enforceable"146 and has considered the waivability of statutory treble damages in light of their similarity or lack thereof to punitive damages. ${ }^{147}$ Recent decisions have not treated antitrust treble damages as punitive for purposes of arbitration agreements, ${ }^{148}$ but some older authority does describe antitrust law's trebling provision as a form of punitive damages. ${ }^{149}$ On the other hand, some federal courts have held that waivers of antitrust law's provision for mandatory treble damages are against public policy and therefore invalid. ${ }^{150}$ Still other courts, however, have held that it is up to arbitrators rather than judges to determine whether a damage-limitation provision is unenforceable on public policy grounds. ${ }^{151}$

It remains to be seen whether judges or arbitrators will police the availability of treble damages, whether arbitrators will in fact treble damages, and whether a rule requiring them to treble would - as a practical matter-be enforceable. Some commentary assumes that arbitrators will treble damages because they can. ${ }^{152}$ However, in the absence of clear Supreme Court precedent and a basis for meaningful appeal, "[i]t is not clear whether arbitration tribunals are obliged to award mandatory treble damages by virtue of the Clayton Act." 153 While some commentators during the American Safety era asserted that arbitrators could be required to treble

146 Inv. Partners, L.P. v. Glamour Shots Licensing, Inc., 298 F.3d 314, 318 n.1 (5th Cir. 2002) (citing Mastrobuono v. Shearson Lehman Hutton, Inc., 514 U.S. 52, 56-57 (1995)). But see In re Cotton Yarn Antitrust Litig., 505 F.3d 274, 300 (4th Cir. 2007) (Johnston, J., concurring in part and dissenting in part) ("Applying these principles, our sister circuits have consistently invalidated arbitration agreements that proscribe the arbitral award of damages guaranteed by statute.").

147 See, e.g., Inv. Partners, 298 F.3d at 316-18 (5th Cir. 2002).

148 See, e.g., id. at 317 (holding that treble damages are compensatory and accordingly "the prohibition in the parties' arbitration agreement against awarding 'punitive damages' does not extend to statutory treble damages"); McCallum \& McCareins, supra note 69, at 21 ("[C]ourts have generally upheld arbitration agreements prohibiting the award of 'punitive damages,' but also have ruled that such limitations do not constrain the arbitrators' power to award statutory treble damages." (endnotes omitted)).

149 See, e.g., Comm'r v. Obear-Nester Glass Co., 217 F.2d 56, 61 (7th Cir. 1954) (“[T]he principal purpose of treble damages seems to be punishment which will deter the violator and others from future illegal acts.").

${ }^{150}$ See, e.g., Kristian, 446 F.3d at 46 ("[U]nder federal law, the remedies provided by the antitrust statute cannot be contractually waived."); James C. Justice Cos., Inc. v. Deere \& Co., No. 5:06-cv-00287, 2008 WL 828923, at *4 (S.D. W. Va. Mar. 27, 2008) ("[T]reble damages as provided for in the Sherman Act is a non-waivable substantive right."); see also Graham Oil Co. v. ARCO Prods. Co., 43 F.3d 1244, 1246-48 (9th Cir. 1995) (declining to enforce an arbitration clause that circumvented the statutory remedies of the Petroleum Marketing Practices Act).

151 See Larry's United Super, Inc. v. Werries, 253 F.3d 1083, 1085-86 (8th Cir. 2001) (addressing treble damages under RICO).

152 See Buffon \& Wolson, supra note 68 , at 34.

153 Baker \& Stabile, supra note 4, at 410 n. 85 . 
damages, ${ }^{154}$ such a requirement would be unenforceable in light of the limited grounds for appealing arbitrators' decisions, as well as the lack of any record in many cases to prove that the arbitrator acted improperly. ${ }^{155}$ Moreover, by design, arbitrators are invested with discretion, which may include the power to ignore trebling. ${ }^{156}$ In their quest for reaching a compromise solution, arbitrators may be emboldened to award single damages, instead of trebled damages. ${ }^{157}$ Even if the arbitration clause does not expressly waive trebling, the arbitrator could decide not to treble in response to defendants' request or sua sponte in the name of compromise or perceived fairness.

In sum, treble damages play a critical role in vindicating antitrust policy, and leaving trebling up to arbitrators would risk the continuing viability of that remedy. An arbitrator's decision not to treble antitrust damages would ultimately undermine both the deterrence ${ }^{158}$ and compensation functions of federal antitrust law. The only way to ensure the trebling of damages is by removing antitrust claims from private arbitration and into public courts. ${ }^{159}$

2. Injunctive Relief.-In addition to treble damages, federal antitrust law also provides for injunctive relief when appropriate. ${ }^{160}$ In antitrust jurisprudence, "injunctive relief has three primary purposes: '(1) putting an end to illegal conduct, (2) depriving violators of the benefits of their illegal

154 Finn, supra note 92, at 416 ("Nor would it be inconsistent with arbitration policy to require arbitrators to give effect to the treble damage and cost provisions."); see also Kristian, 446 F.3d at 48 ("[T]he arbitrator must award treble damages for a federal antitrust violation.").

155 See FED. TRADE COMM'N, supra note 95, at v ("Arbitrators rarely accompany awards with an opinion setting forth a statement of the law and an application of the law to the facts, which makes it difficult to understand the basis for the award."); Finn, supra note 92, at 413 ("The merits of an award are not reviewable, and a court may not vacate or modify an award because of disagreement with the arbitrators' interpretation of the law or facts." (citing Wilko v. Swan, 346 U.S. 427, 436 (1953); Raytheon Co. v. Rheem Mfg. Co., 322 F.2d 173, 182-83 (9th Cir. 1963); San Martine Compania De Navegacion, S.A. v. Saguenay Terminals Ltd., 293 F.2d 796, 800 (9th Cir. 1961); James Richardson \& Sons v. W.E. Hedger Transp. Corp., 98 F.2d 55, 57 (2d Cir. 1938))).

156 Pitofsky, supra note 107, at 1079 (“A key technique devised by Congress to encourage private antitrust litigation and enlarge penalties against those found to have violated the antitrust laws are the provisions calling for mandatory treble damages and attorney's fees for the plaintiff. In the ordinary commercial arbitration, neither of those statutory provisions would be binding on the arbitrator.").

157 Fuglsang, supra note 111, at 815 ("Because arbitration is designed primarily to reach a fair settlement or compromise between the parties, arbitrators are more likely to award only actual damages rather than the statutorily mandated treble damages.").

158 Mark R. Lee, Antitrust and Commercial Arbitration: An Economic Analysis, 62 ST. JoHN's L. REV. 1, 4 (1987).

159 Cf. Pitofsky, supra note 107, at 1079 ("[A] binding referral to arbitration (where rights to treble damages and attorneys' fees could not be secure) . . . should be unenforceable.").

16015 U.S.C. $\S 26$ (2012). Both government and private plaintiffs can request injunctions to remedy antitrust violations. Id. $\S \S 25-26$. 
conduct, and (3) restoring competition in the marketplace." "161 As with treble damages, Congress created "injunctive remedies ... not merely to provide private relief, but... to serve as well the high purpose of enforcing the antitrust laws."162 Unlike damages, however, injunctive relief "is characteristically available even though the plaintiff has not yet suffered actual injury; he need only demonstrate a significant threat of injury from an impending violation of the antitrust laws or from a contemporary violation likely to continue or recur." 163

Antitrust arbitration has the potential to undermine the injunctive relief component of private antitrust enforcement. In theory, "[a]rbitrators enjoy broad equitable powers ... [to] grant whatever remedy is necessary to right the wrongs within their jurisdiction." 164 Some arbitration clauses explicitly provide that an arbitrator may issue an injunction. ${ }^{165}$ In practice, however, potential antitrust defendants can easily draft their arbitration clauses to preclude any arbitrator from granting the plaintiff injunctive relief. ${ }^{166}$

The possibility of antitrust defendants using arbitration clauses to prevent injunctions is alarming because equitable remedies are often important in private antitrust lawsuits. ${ }^{167}$ Federal judges can structure antitrust injunctions to eliminate the "lingering effects" of illegal anticompetitive conduct. ${ }^{168}$ In contrast, private arbitrators have less incentive and less institutional competence to impose, monitor, and enforce sweeping injunctive relief to restore and maintain competitive markets.

161 Arthur S. Langenderfer, Inc. v. S.E. Johnson Co., 729 F.2d 1050, 1059 (6th Cir. 1984) (quoting In re Multidistrict Vehicle Air Pollution, 538 F.2d 231, 234 (9th Cir. 1976)).

162 Zenith Radio Corp. v. Hazeltine Research, Inc., 395 U.S. 100, 130-31 (1969).

163 Id. at 130 (citation omitted).

164 HCI Techs, Inc., v. Avaya, Inc., 241 F. App'x 115, 125 n.12 (4th Cir. 2007) (per curiam) (first alteration in original) (quoting Gilmer v. Interstate/Johnson Lane Corp., 895 F.2d 195, 199 (4th Cir. 1990), aff'd, 500 U.S. 20 (1991)).

165 See, e.g., AT\&T Mobility LLC v. Concepcion, 131 S. Ct. 1740, 1744 (2011).

166 James J. Calder et al., A New Alternative to Antitrust Litigation: Arbitration of Antitrust Disputes, ANTITRUST, Spring 1989, at 18, 19-20 (explaining that "parties to an arbitration generally . . . can limit the remedies available" and arguing that "[t]he attraction of arbitration may be further enhanced if the remedies available to the arbitrators are limited so as to exclude injunctive relief").

167 See, e.g., In re Visa Check/MasterMoney Antitrust Litig., 192 F.R.D. 68, 88 (E.D.N.Y. 2000) (finding antitrust action qualified for class certification "[b]ecause the highly significant injunctive relief sought here is as important as the damages claimed").

168 See, e.g., Wilk v. Am. Med. Ass'n, 895 F.2d 352, 366-67 (7th Cir. 1990). 
3. Attorneys' Fees and Costs.-Antitrust law's statutory regime is unusual in that it requires the successful private plaintiff-but not the successful defendant - to receive reasonable attorneys' fees and costs. ${ }^{169}$ Like trebling, the award of attorneys' fees to successful antitrust plaintiffs is mandatory. ${ }^{170}$ This automatic award of attorneys' fees facilitates the policy goals of "both encourag[ing] 'private prosecution of antitrust violations by insulating plaintiffs' treble damage recoveries from the expense of legal fees' and deter[ring] violation of the antitrust laws by requiring a losing defendant to pay the plaintiffs' attorneys' fees 'as part of his penalty for having violated the antitrust laws." ${ }^{171}$ The compulsory award of costs to antitrust victims vindicates "the public interest in vigilant enforcement of the antitrust laws through the instrumentality of the private treble-damage action." 172

Despite this statutory command, arbitration clauses often require that both winners and losers pay their own attorneys' fees, ${ }^{173}$ thus attempting to override antitrust law's mandatory fee-shifting provision for successful antitrust plaintiffs. Unlike federal judges, arbitrators are not necessarily forced to follow antitrust law's statutory mandate of fee shifting when the plaintiffs prevail. ${ }^{174}$ Courts in some non-antitrust cases have invalidated arbitration clauses that purported to deny a successful plaintiff recovery of statutorily mandated reasonable attorneys' fees. ${ }^{175}$ The validity of anti-feeshifting arbitration clauses in antitrust disputes was unsettled even prior to Italian Colors. Some antitrust courts used the Effective Vindication Doctrine to invalidate such contract provisions on the grounds that a "ban on the recovery of attorney's fees and costs ... would burden Plaintiffs ... with prohibitive arbitration costs, preventing Plaintiffs from vindicating their

16915 U.S.C. $\S 15$ (2012) (““A]ny person who shall be injured in his business or property by reason of anything forbidden in the antitrust laws may sue therefor ... and shall recover threefold the damages by him sustained, and the cost of suit, including a reasonable attorney's fee.").

170 Alyeska Pipeline Serv. Co. v. Wilderness Soc'y, 421 U.S. 240, 261 (1975) (“Under the antitrust laws, for instance, allowance of attorneys' fees to a plaintiff awarded treble damages is mandatory.").

171 Sciambra v. Graham News, 892 F.2d 411, 416 (5th Cir. 1990) (citations omitted) (quoting Home Placement Serv. v. Providence Journal Co., 819 F.2d 1199, 1210 (1st Cir. 1987); Farmington Dowel Prods. Co. v. Forster Mfg. Co., 421 F.2d 61, 90 (1st Cir. 1969)).

172 Mitsubishi Motors Corp. v. Soler Chrysler-Plymouth, Inc., 473 U.S. 614, 653 (1985) (Stevens, J., dissenting) (quoting Lawlor v. Nat'1 Screen Serv. Corp., 349 U.S. 322, 329 (1955))

173 See, e.g., Graham Oil Co. v. ARCO Prods. Co., 43 F.3d 1244, 1247 (9th Cir. 1995) ("[T]he arbitration clause expressly forfeits Graham Oil's statutorily-mandated right to recover reasonable attorney's fees from ARCO if Graham Oil prevails on certain claims. The clause provides that each party will bear its own attorney's fees.").

174 See Baker \& Stabile, supra note 4, at 428 (suggesting that "the arbitrator might be given broad discretion to allocate fees and costs").

175 See Brewer, supra note 85, at 119-20. 
statutory rights in arbitration." ${ }^{176}$ However, other pre-Italian Colors courts upheld arbitration clauses that preclude any arbitrator from awarding attorneys' fees to a successful antitrust plaintiff. ${ }^{177}$

Some arbitration clauses go further and include double-edged feeshifting provisions that require the unsuccessful antitrust plaintiff to pay the defendants' costs. ${ }^{178}$ Such an approach can deter frivolous litigation, ${ }^{179}$ but it can also deter valid antitrust suits. ${ }^{180}$ The drafters of American antitrust law explicitly rejected the English rule-where the losing party pays the reasonable attorneys' fees of both sides - in favor of a one-sided fee-shifting regime in which only successful plaintiffs benefit. Arbitration clauses that seek to impose the English rule are inconsistent with the clear text of antitrust statutes and may deter victims of antitrust violations from bringing valid claims.

Fee-shifting for successful antitrust plaintiffs is particularly important for equitable cases brought under Section 16 of the Clayton Act. The plaintiff seeking injunctive relief must recover its costs if successful; otherwise, even if it wins, it is essentially paying for an injunction (of perhaps dubious strength) to get the defendant to follow the law. When Congress was considering the Hart-Scott-Rodino Antitrust Improvements Act of 1976, ${ }^{181}$ the House Report noted:

[T]he need for the awarding of attorneys' fees in $\S 16$ injunction cases is greater than the need in $\S 4$ treble damage cases. In damage cases, a prevailing plaintiff recovers compensation, at least. In injunction cases, however, without the shifting of attorneys' fees, a plaintiff with a deserving case would personally have to pay the very high price of obtaining judicial enforcement of the law and of the important national policies the antitrust laws reflect. A prevailing plaintiff should not have to bear such an expense. Section 3(3) of H.R. 8532, therefore, is intended to reiterate congressional encouragement for private parties to bring and maintain meritorious antitrust injunction cases. Under this section, a

\footnotetext{
176 Kristian v. Comcast Corp., 446 F.3d 25, 52-53 (1st Cir. 2006). In Kristian, the court severed the fee clause because the governing contract had a savings clause. Id. at 53 .

177 See, e.g., James C. Justice Cos., v. Deere \& Co., No. 5:06-cv-00287, 2008 WL 828923, at *5 (S.D. W. Va. Mar. 27, 2008) ("[The plaintiff] has offered no evidence that paying its own attorney's fees and costs in arbitration would prevent it from effectively vindicating its rights under the Sherman Act. Therefore, Court cannot conclude that the Dealership Agreement's limitation on attorney's fees and costs is inconsistent with the policies of the Sherman Act.").

178 See, e.g., In re Pharmacy Benefit Managers Antitrust Litig., 700 F.3d 109, 112 (3d Cir. 2012).

179 Baker \& Stabile, supra note 4, at 428.

180 See Gilles \& Friedman, supra note 35, at 635 (noting that a fee-shifting provision can chill plaintiffs from bringing suit); id. at 645 ("[B]ounty and fee-shifting clauses are plainly intended to avoid liability and not to select an alternative forum for the resolution of disputes.").

181 Pub. L. No. 94-435, 90 Stat. 1383 (1976) (codified in scattered sections of 15 U.S.C.).
} 
plaintiff who substantially prevails would be entitled to the award of "reasonable attorneys' fees." 182

Absent fee-shifting, given the cost and uncertainty of antitrust adjudication, the victims of an antitrust violation may have insufficient incentive to pursue an equitable remedy. ${ }^{183}$ If so, antitrust violations would become more profitable, and thus, more likely.

For the same reasons that antitrust defendants should not be able to detreble antitrust damages through a cleverly worded limitation clause in an arbitration agreement, neither should they be able to nullify the Sherman Act's attorneys' fees provision by the same means. Treble damages and the automatic award of reasonable attorneys' fees and costs to successful antitrust plaintiffs serve the same function and neither should be circumvented through arbitration. ${ }^{184}$

4. Statutes of Limitations. - Federal antitrust law provides a four-year statute of limitations. ${ }^{185}$ Prior to 1955 , because federal antitrust statutes did not define a limitations period, federal courts used "the most analogous state statute of limitations" to determine the filing deadline for private antitrust actions. ${ }^{186}$ In 1955, Congress amended the Clayton Act to establish a uniform four-year statute of limitations for all private antitrust claims. ${ }^{187}$ This is a relatively generous period that facilitates private causes of action. ${ }^{188}$ Four years affords potential antitrust plaintiffs sufficient time to discover violations and investigate their claims before filing suit, which is particularly important given that the Supreme Court has significantly increased the

182 F. \& M. Schaefer Corp. v. C. Schmidt \& Sons, 476 F. Supp. 203, 205 n.1 (S.D.N.Y. 1979) (quoting 1976 U.S.C.C.A.N. 2572, 2589).

183 Baker, supra note 127, at 386 ("[T] he one-way cost rule seems most important . . . in equity cases under Section 16 of the Clayton Act. The fact that such a plaintiff can recover costs is definitely an incentive to seek an injunction.").

184 Indeed, they share the same sentence of the Sherman Act. 15 U.S.C. $§ 15$ (2012).

$185 \mathrm{Id}$. $15 \mathrm{~b}$

186 In re Cotton Yarn Antitrust Litig., 505 F.3d 274, 289 (4th Cir. 2007).

187 Id.

188 Cf. Securities Exchange Act of 1934 § 9(f), 15 U.S.C. § 78i (2012) ("No action shall be maintained to enforce any liability created under this section, unless brought within one year after the discovery of the facts constituting the violation and within three years after such violation."); Telecommunications Act $\S 415,47$ U.S.C. $\S 415$ (two-year statute of limitations); DelCostello v. Int'l Bhd. of Teamsters, 462 U.S. 151, 169 (1983) ("[Section] 10(b) of the National Labor Relations Act ... establishes a 6-month period for making charges of unfair labor practices to the NLRB."); Onyx Props. LLC v. Bd. of Cty. Comm'rs of Elbert Cty., 868 F. Supp. 2d 1164, 1167-68 (D. Colo. 2012) (“[A]ll actions upon liability created by a federal statute where no period of limitation is provided in said federal statute ... shall be commenced within two years after the cause of action accrues." (ellipsis in original) (quoting COLO. REV. STAT. § 13-80-102(1)(g) (2012)). 
burden that antitrust plaintiffs must overcome to survive a motion to dismiss. ${ }^{189}$

In drafting their contracts with suppliers and consumers, potential antitrust defendants have crafted and included arbitration clauses that significantly shorten the statute of limitations for antitrust claims. For example, many businesses have employed contract terms that require any arbitration to be initiated within one year of "the event or facts giving rise to a dispute." 190 Private agreements to abbreviate statutory limitations periods conflict with legislative determinations of the appropriate amount of time to afford plaintiffs to bring suit.

Courts vary in their willingness to enforce arbitration agreements that truncate statutes of limitations. Some states prohibit contractual shortening of statutes of limitation, ${ }^{191}$ but others do not. ${ }^{192}$ Some federal judges have proven receptive to antitrust defendants shortening the statute of limitations through arbitration provisions, ${ }^{193}$ and courts have rejected claims that arbitration clauses that significantly reduce a statute of limitations make antitrust claims nonarbitrable. ${ }^{194}$

Some courts have treated plaintiffs' arguments against truncated statutes of limitations with hostility, belittling them as "little more than an observation that the limitations period under the arbitration agreements is shorter than that provided by federal law and the unremarkable recognition that limitations provisions affect the amount of damages that may be recovered." 195 In rejecting plaintiffs' arguments, federal courts have asserted that statutes of limitations present issues of procedure, not substantive antitrust law. ${ }^{196}$ Judges have reasoned that in creating the four-year statute of

189 See Bell Atl. Corp. v. Twombly, 550 U.S. 544, 556 (2007).

190 See, e.g., Cotton Yarn, 505 F.3d at 287 ("The arbitration agreements ... establish a one-year period in which claims must be brought."); Kristian v. Comcast Corp., 446 F.3d 25, 43 (1st Cir. 2006) ("[T]he 2002/2003 arbitration agreements state that "you must contact us within one (1) year of the date of the occurrence of the event or facts giving rise to a dispute . . or you waive the right to pursue a claim based upon such event, facts or dispute."' (ellipsis in original)).

191 See Cotton Yarn, 505 F.3d at 287 n.8 (noting South Carolina law).

192 See id. (noting North Carolina law).

193 Buffon \& Wolson, supra note 68, at 35 ("[A]n arbitration agreement that requires the parties to file their claim within one year after becoming aware of a claim has been held enforceable, even when the statute of limitations period would otherwise be longer." (citing Morrison v. Circuit City Stores, Inc., 70 F. Supp. 2d 815, 826-27 (S.D. Ohio 1999))); see, e.g., James C. Justice Cos. v. Deere \& Co., No. 5:06cv-00287, 2008 WL 828923, at*5 (S.D. W. Va. Mar. 27, 2008) (enforcing a mandatory arbitration clause with a two-year statute of limitations because the plaintiff had brought its claim within two years).

194 See, e.g., Kristian, 446 F.3d at 44 ("[W]e conclude that Plaintiffs" challenge to the statute of limitations contained in the 2002/2003 Policies \& Practices does not raise a question of arbitrability.").

195 Cotton Yarn, 505 F.3d at 288.

196 See id. at 289 ("And the Eighth Circuit, in a case decided not long after $\S 15$ b was enacted (but which did not involve questions of arbitration), likewise viewed the limitations period as procedural rather 
limitations, Congress merely intended to create a uniform statute of limitations for federal antitrust claims to replace the patchwork of state statutes of limitations that federal courts had been using in the absence of a specified federal statute of limitations for antitrust claims. ${ }^{197}$ For example, the Fourth Circuit in Cotton Yarn asserted:

If Congress was content for so long to permit antitrust plaintiffs to be subject to different limitations periods (which of course affected the amount of damages that could be recovered), it seems difficult to conclude that Congress, by merely establishing a uniform limitations period, intended to vest plaintiffs in all antitrust cases with a substantive and non-waivable right to wait four years before bringing suit and to recover a full four years' worth of damages. ${ }^{198}$

Cotton Yarn assumed that Congress was solely concerned with uniformity and not protecting the substantive rights of antitrust plaintiffs with a generous statute of limitations. ${ }^{199}$ Furthermore, the Clayton Act does not explicitly forbid parties from shortening the four-year statute of limitations. ${ }^{200}$ Consequently, according to the Fourth Circuit, parties can use arbitration clauses to shorten the antitrust limitations period because doing so is not a waiver of any substantive rights. ${ }^{201}$

The argument that Congress wasn't creating a substantive right when it established antitrust's statute of limitations is suspect for at least two reasons. First, it ignores the fact that Congress made the uniform statute of limitations for federal antitrust claims four years, which is relatively long. This suggests that Congress's concern went beyond uniformity - that it also wanted to preclude shorter state statutes from interfering with effective antitrust enforcement. Second, Congress chose not to create uniformity when it decided not to preempt longer state antitrust statutes of limitations. ${ }^{202}$ The decision not to exercise its preemptory powers meant Congress allowed for

than substantive. See Kansas City v. Fed. Pac. Elec. Co., 310 F.2d 271, 282-83 (8th Cir. 1962). We also believe that $\S 15 \mathrm{~b}$ should not be viewed as establishing substantive rights."); Kristian, 446 F.3d at 43 (describing statute of limitations as a procedural issue).

197 See Cotton Yarn, 505 F.3d at 289 n.9 (discussing legislative history of 15 U.S.C. § 15b). But see $i d$. at 298-99 (Johnston, J., concurring in part and dissenting in part) ("I would hold that the four-year limitations period contained in 15 U.S.C. $\S 15 \mathrm{~b}$ is a non-waivable substantive right, and that the purported waiver of this right would, in this case, prevent the plaintiffs from effectively vindicating their statutory rights.").

198 Id. at 289

199 Id. at 289 n.9.

${ }^{200} \mathrm{Id}$. at 287.

2011 ABA Section of Antitrust Law, ANTitrust Law DeVElopments 808 (7th ed. 2012) ("The limitations period, however, is not considered a substantive element of the federal antitrust laws, and thus the period may be shortened by contract.").

202 Connecticut v. Levi Strauss \& Co., 471 F. Supp. 363, 367 n.3 (D. Conn. 1979) (discussing Ohio ex rel. Brown v. Klosterman French Baking Co., No. C-1-75-338, 1976 WL 1373 (S.D. Ohio June 18, 1976)). 
disuniformity regarding supplemental state antitrust claims. The Sixth Circuit has explained that " $[\mathrm{s}]$ ince Congress was well aware that there were state antitrust laws in effect and chose not to preempt them, we believe that neither did it intend to preempt anything in them, including statutes of limitations ... . " ${ }^{203}$ Far from preempting these state laws with longer statute of limitations, "Congress recognized and approved state antitrust statutes of limitations, including those longer than four years."204 That suggests Congress intended to impose a minimum period for antitrust enforcement.

Even where courts permit agreements to truncate limitations periods, antitrust defendants do not enjoy unlimited power to shorten the statute of limitations. Under Cotton Yarn, for example, an arbitration clause cannot mandate a limitations period that is "unreasonably short." 205 The opinion, however, suggests that this is unlikely to be a meaningful constraint in the antitrust context. Invoking non-antitrust examples, the Fourth Circuit held that arbitration clauses that shorten the antitrust statute of limitations to just one year are reasonable. ${ }^{206}$ This conclusion is suspect given the realities of antitrust litigation. A one-year statute of limitations would afford antitrust plaintiffs scarce time to develop facts sufficient to satisfy Twombly's new higher pleading standard for antitrust cases. ${ }^{207}$ Discovering the fact of a cartel may take time, and collecting evidence sufficient to satisfy Twombly may take yet more time. But in the new world of arbitration, plaintiffs may be forced to bring underdeveloped cases or risk losing their claims forever.

Even with respect to those claims that plaintiffs manage to bring within such a narrowed time frame, allowing potential antitrust defendants to truncate the statute of limitations could seriously undermine antitrust policy by significantly reducing the damages awarded to successful antitrust plaintiffs. Because antitrust damages are generally calculated for the period of activity covered by the applicable statute of limitations, shortening the statute of limitations can also reduce the damages available to a successful

203 Pinney Dock \& Transp. Co. v. Penn Cent. Corp., 838 F.2d 1445, 1482 (6th Cir. 1988).

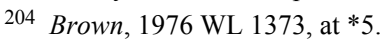

205 Cotton Yarn, 505 F.3d at 287; see also Buffon \& Wolson, supra note 68, at 35 ("Parties generally have the power to shorten a statute of limitations by contract, so long as the agreement is reasonable under the circumstances.").

206 Cotton Yarn, 505 F.3d at 287 ("Courts have frequently found contractual limitations periods of one year (or less) to be reasonable.")

207 See Bell Atl. Corp. v. Twombly, 550 U.S. 544, 556 (2007). Arbitrators, too, can grant a quasimotion to dismiss. See Am. Arbitration Ass'n, COnSumer Arbitration Rules 25 (2014), https://www.adr.org/aaa/ShowProperty?nodeId=/UCM/ADRSTAGE2021425\&revision=latestreleased [https://perma.cc/E242-3YAG]. 
antitrust plaintiff. ${ }^{208}$ Courts have been less sympathetic towards this argument than they have been towards efforts to avoid waiver of treble damages. While some courts have suggested that arbitration clauses banning treble damages may be unenforceable because the "right to recover treble damages is a substantive right," ${ }^{209}$ they have permitted truncating the statute of limitations from four years to one. ${ }^{210}$

This is incongruous because a one-year statute of limitations may reduce damages - and thus undermine the deterrence and compensation goals of antitrust law-more than detrebling. Detrebling cuts damages by two-thirds, but reducing the statute of limitations from four years to one can cut damages by three-fourths. Courts elevate the "particular type of damages" over "the amount of the award" 211 despite the fact that it is the amount of damages that determines compensation and deterrence, not the label attached to those damages. Invoking the procedure-versus-substance mantra, the Fourth Circuit has held that defendants can use arbitration clauses to significantly reduce the successful antitrust plaintiff's recovery: "[W]e cannot conclude that the arbitral forum is inadequate or inaccessible merely because the plaintiff may recover a lesser quantum of damages than he might have in a judicial forum." ${ }^{212}$ The court failed to appreciate that this undermines the deterrent effect of the antitrust regime. ${ }^{213}$

In allowing antitrust defendants to shorten the statute of limitations, some courts have pointed to the doctrine of fraudulent concealment as sufficient to protect antitrust plaintiffs. ${ }^{214}$ Applying this doctrine means that if an antitrust plaintiff can establish that the defendant wrongfully concealed its antitrust violation ${ }^{215}$ and that the plaintiff exercised due diligence, then the

\footnotetext{
208 See Cotton Yarn, 505 F.3d at 299-300 (Johnston, J., concurring in part and dissenting in part) ("[W] $[\mathrm{Wile}$ the Antitrust Act effectively requires a four year look-back period, the contract at issue would only allow the arbitrator to consider one year of anti-competitive behavior.").

${ }^{209}$ Id. at 288 (majority opinion) (discussing Kristian v. Comcast Corp., 446 F.3d 25, 48 (1st Cir. 2006)).

210 Id.

211 Id. at 300-01 (Johnston, J., concurring in part and dissenting in part).

212 Id. at 290 (majority opinion).

213 See Christopher M. Huber, Summary, In re Cotton Yarn Antitrust Litigation, 60 S.C. L. REV. 1177, 1187-88 (2009) ("'P] $]$ unishing the defendants for only one year of anti-competitive activity would not have the same deterrent effect as holding them accountable for the entire four year statutory period and likely would not fully compensate the plaintiffs.").

214 Cotton Yarn, 505 F.3d at 291 ("The plaintiffs' contention that a one-year limitations period would prevent them from proceeding on their antitrust claims also fails to account for the doctrine of fraudulent concealment, which is read into all federal statutes of limitations, including $\S 15 \mathrm{~b} . . . "$ " (citations omitted)).

215 "In the absence of a fiduciary duty or other affirmative obligation to make disclosure, the defendant's silence also is not enough." 1 ABA SECTION OF ANTITRUST LAW, supra note 201, at 816-17 (footnote omitted).
} 
statute of limitations does not begin to run until the plaintiff knew, or in the exercise of reasonable diligence should have known, of the antitrust violation. ${ }^{216}$ The statute of limitations is "tolled" until one or the other occurs. In federal antitrust cases, the antitrust plaintiff is then afforded "the full fouryear period" provided by the antitrust statute to bring a claim. ${ }^{217}$ Cotton Yarn concluded that a one-year period for bringing an arbitration claim was sufficient in part because the year wouldn't start running until the plaintiffs had learned of the defendant's antitrust violations. ${ }^{218}$

Tolling could affect the analysis. Cotton Yarn assumed that tolling applies to claims brought in arbitration. The doctrine of fraudulent concealment is read into otherwise silent federal statutes, and some courts have applied it to antitrust arbitration claims in the absence of objections from the defendant. ${ }^{219}$ Thus, in theory, the tolling provisions of antitrust law can expand antitrust plaintiffs' period for filing a lawsuit beyond the truncated statute of limitations found in an arbitration clause. ${ }^{220}$ Some arbitration provisions, however, attempt to prohibit equitable tolling, effectively converting a statute of limitations into a statute of repose that cannot be tolled. ${ }^{221}$ If arbitrators enforce these contract terms, antitrust plaintiffs can be out of luck without any recourse.

Prior to Italian Colors, at least, the Effective Vindication Doctrine served as a moderating influence on efforts to use arbitration clauses to limit substantive rights. ${ }^{22}$ If the shortening of the limitations period prevents the plaintiff from effectively vindicating its rights, that could undermine the enforceability of the arbitration clause. ${ }^{223}$ At a minimum, provisions to truncate the limitations period should be severed from the arbitration

$216 I d$. at 816 (collecting cases).

217 Id.

218505 F.3d at 291

219 See, e.g., In re Cotton Yarn Antitrust Litig., No. 1:04MD1622, 2009 WL 618252, at*4 (M.D.N.C. Mar. 6, 2009) ("Defendants do not dispute Plaintiffs' contention that the doctrine of fraudulent concealment applies.”).

220 Traditionally, the tolling provisions effectively lengthen the antitrust statute of limitations. Milton Handler, Antitrust-1978, 78 CoLUM. L. REV. 1363, 1411-12 (1978).

221 Merrill Lynch, Pierce, Fenner \& Smith, Inc. v. Cohen, 62 F.3d 381, 382 (11th Cir. 1995); Christopher R. Leslie, Den of Inequity: The Case for Equitable Doctrines in Rule 10b-5 Cases, 81 CALIF. L. REV. 1587, 1591 (1993) (explaining statutes of repose).

222 See Cotton Yarn, 2009 WL 618252, at *4 ("The Court therefore concludes that the contractual one-year limitations period set forth in the arbitration agreements at issue does not prevent Plaintiffs from proceeding with their antitrust claims in the arbitral forum, and furthermore, that the arbitration agreements at issue in this case do not prevent Plaintiffs from effectively vindicating their statutory rights.").

223 See Huber, supra note 213, at 1183-84 (“[T] he court considered whether, if the plaintiffs' claims were held untimely under the arbitration agreements, it would prevent the plaintiffs from effectively vindicating their statutory rights."). 
agreement. ${ }^{224}$ With the weakening of the Effective Vindication Doctrine affected by Italian Colors, antitrust defendants will be more tempted to use arbitration clauses to significantly truncate statutes of limitations and thus reduce expected damages from antitrust violations. ${ }^{225}$

\section{Class Actions}

Class action litigation is a critical part of the antitrust enforcement regime. Class actions make it possible for thousands of victims of an antitrust violation to collectively seek relief for damage awards that would be too small to justify the cost of pursuing in individual litigation. ${ }^{226}$ In theory, classwide arbitration could serve this same aggregating function. ${ }^{227}$ The Supreme Court, however, has been skeptical of class arbitration, in part because of the lack of review, which hurts the losing defendant considerably when thousands of claims are aggregated into one high-stakes adjudication. ${ }^{228}$

Many arbitration clauses explicitly preclude both class action litigation and class-wide arbitration. ${ }^{229}$ This is highly advantageous for potential antitrust defendants, because eliminating class action litigation and class arbitration may - as a practical matter - eliminate liability. By requiring that their customers waive any right to participate in a class action, antitrust

${ }^{224}$ See In re Cotton Yarn Antitrust Litig., 505 F.3d 274, 301 (4th Cir. 2007) (Johnston, J., concurring in part and dissenting in part).

${ }^{225} C f$. Brewer, supra note 85, at 119 ("Parties might be tempted, for example, to include provisions providing that an antitrust claim must be brought within an abbreviated time period or it is waived, notwithstanding the four-year statute of limitations prescribed in 15 U.S.C. § 15(b).”).

Complicating the issue further is who decides the issue. Arbitration clauses sometimes provide that the issue of whether the truncated statute of limitations is permissible should be submitted to the court, not the arbitrator. In re Cotton Yarn Antitrust Litig., 406 F. Supp. 2d 585, 590 (M.D.N.C. 2005), vacated, 505 F.3d 274 (4th Cir. 2007). But that is not required by law and if an arbitration agreement were to reserve this question for the arbitrator, this would substantially undermine the Effective Vindication Doctrine because the arbitrator is not bound by the law in the same manner as a federal judge.

226 See Christopher R. Leslie, De Facto Detrebling, supra note 129, at 1011-12 (noting that most price-fixing cases are brought as class actions).

227 The American Arbitration Association (AAA) has developed class arbitration procedures, which largely mimic Federal Rule of Civil Procedure 23. AT\&T Mobility LLC v. Concepcion, 131 S. Ct. 1740, 1751 (2011). The Supreme Court has suggested that arbitrators may not be up to the task of adjudicating the legal issues involved in class procedures, such as certification. Id. at 1750. It seems to hold that arbitrators are smart enough to decide complicated antitrust matters, but not to understand class certification.

228 See, e.g., Concepcion, 131 S. Ct. at 1752; Stolt-Nielsen S.A. v. AnimalFeeds Int'l Corp., 559 U.S. 662, 684-87 (2010). The Supreme Court has not, however, expressed a similar concern about the losing plaintiff. The Court seems to only care about arbitration error and lack of review when it could hurt the defendant. For a discussion of the increasing challenges facing antitrust class actions, see Spencer Weber Waller, The Fall and Rise of the Antitrust Class Action (working paper August 10, 2015), http://papers.ssrn.com/sol3/papers.cfm?abstract_id=2641867 [http://perma.cc/8YZE-QCYE].

229 See, e.g., Concepcion, 131 S. Ct. at 1744 ("The contract provided for arbitration of all disputes between the parties, but required that claims be brought in the parties' 'individual capacity, and not as a plaintiff or class member in any purported class or representative proceeding."'). 
defendants prevent the "spreading across multiple plaintiffs the costs of experts, depositions, neutrals' fees, and other disbursements[, which] forces the individual claimant to assume financial burdens so prohibitive as to deter the bringing of claims." ${ }^{230}$ Even if individual arbitration is cheaper than individual litigation, arbitration is still prohibitively expensive for a lone plaintiff to pursue an antitrust claim, as demonstrated by the facts of Italian Colors. ${ }^{231}$ As the Seventh Circuit has noted, "[t]he realistic alternative to a class action is not 17 million individual suits, but zero individual suits, as only a lunatic or a fanatic sues for $\$ 30 . "{ }^{232}$ With class actions barred, pursuing individual arbitration would be irrational, and antitrust violators would have functionally immunized themselves from private suit. ${ }^{233}$

Arbitration clauses that prohibit litigating or arbitrating as a class thwart both the substantive and procedural laws that Congress designed to protect consumers. Substantively, class action waivers undermine the effective vindication of rights, as the First Circuit has recognized: "[A] bar on class arbitration threatens the premise that arbitration can be 'a fair and adequate mechanism for enforcing statutory rights."'234 Procedurally, the primary reason that Congress created the class action vehicle was "to overcome the problem that small recoveries do not provide the incentive for any individual to bring a solo action prosecuting his or her rights." ${ }^{235}$ Many, if not most, individuals will not have the resources to mount an individual case. ${ }^{236}$ Antitrust suits are particularly expensive for plaintiffs to bring because of the necessity for economic experts, whose fees can dwarf an individual claimant's damages. ${ }^{237}$ In many cases, it would be irrational for either victims of antitrust violations or their attorneys to pursue individual litigation or arbitration. ${ }^{238}$ Consequently, class action waivers significantly undermine the

\footnotetext{
230 Myriam Gilles, Opting Out of Liability: The Forthcoming, Near-Total Demise of the Modern Class Action, 104 MiCH. L. REV. 373, 407 (2005).

231 See Am. Express Co. v. Italian Colors Rest., 133 S. Ct. 2304, 2316 (2013) (Kagan, J., dissenting) ("[T]he expense involved in proving the claim in arbitration is ten times what Italian Colors could hope to gain, even in a best-case scenario.”); supra Section I.C. Concepcion provides another example. See 131 S. Ct. at 1761 (Breyer, J., dissenting) ("What rational lawyer would have signed on to represent the Concepcions in litigation for the possibility of fees stemming from a \$30.22 claim?”).

232 Carnegie v. Household Int'1, Inc., 376 F.3d 656, 661 (7th Cir. 2004).

233 See Italian Colors, 133 S. Ct. at 2316 (Kagan, J., dissenting) ("No rational actor would bring a claim worth tens of thousands of dollars if doing so meant incurring costs in the hundreds of thousands.").

234 Kristian v. Comcast Corp., 446 F.3d 25, 54 (1st Cir. 2006) (quoting Rosenberg v. Merrill Lynch, Pierce, Fenner \& Smith, Inc., 170 F.3d 1, 14 (1st Cir. 1999)).

235 Amchem Prods., Inc. v. Windsor, 521 U.S. 591, 617 (1997) (quoting Mace v. Van Ru Credit Corp., 109 F.3d 338, 344 (7th Cir. 1997)).

236 See, e.g., Kristian, 446 F.3d at 54-55.

237 Id. at 58.

238 See Stolt-Nielsen S.A. v. AnimalFeeds Int'l Corp., 559 U.S. 662, 699 (2010) (Ginsburg, J., dissenting) ("When adjudication is costly and individual claims are no more than modest in size, class
} 
deterrent effects and compensatory function of antitrust law. ${ }^{239}$ They may also prevent the continued development of that substantive law by replacing precedential court decisions with private arbitration rulings. ${ }^{240}$

Class action waivers are likely to become more prevalent. ${ }^{241}$ In addition, mandatory arbitration provisions may bind individual class members, preventing them from asserting rights on behalf of the class or forcing those claims to arbitration. ${ }^{242}$ Before Concepcion and Italian Colors, several courts had invalidated class action waivers. ${ }^{243}$ In Italian Colors, however, Justice Scalia belittled the importance of antitrust class actions, asserting that "the individual suit that was considered adequate to assure 'effective vindication' of a federal right before adoption of class-action procedures did not suddenly become 'ineffective vindication' upon their adoption."244 Justice Scalia's contention is flawed for two reasons. First, the Effective Vindication Doctrine postdates the federal class action. Second, and more importantly, Congress created the class action vehicle precisely because victims could not vindicate their rights through individual lawsuits.

Furthermore, some arbitration clauses forbid not only class actions, but all coordination among the victims of an antitrust violation. Arbitration

proceedings may be 'the thing,' i.e., without them, potential claimants will have little, if any, incentive to seek vindication of their rights."); Kristian, 446 F.3d at 59 (citing Jean R. Sternlight \& Elizabeth J. Jensen, Using Arbitration to Eliminate Consumer Class Actions: Efficient Business Practice or Unconscionable Abuse?, 67 LAW \& CONTEMP. PROBS. 75, 85-86 (2004)).

${ }^{239}$ See Jean R. Sternlight, Tsunami: AT\&T Mobility LLC v. Concepcion Impedes Access to Justice, 90 OR. L. REV. 703, 725 (2012) ("If we allow companies to insulate themselves from class actions, we are effectively allowing companies to escape many legal regulations and thereby eliminating a great deterrent to company misconduct.").

240 See, e.g., Myriam E. Gilles, The End of Doctrine: Private Arbitration, Public Law and the AntiLawsuit Movement 33-35, 37-40 (Benjamin N. Cardozo Sch. of Law, Cardozo Legal Studies Research Paper No. 436), http://papers.ssrn.com/sol3/papers.cfm?abstract_id=2488575 [http://perma.cc/3CMPKHKS].

${ }^{241}$ Sternlight, supra note 239, at 718 ("In the near future, we can expect that even more companies will impose arbitral class action waivers as a means to insulate themselves from class actions because Concepcion has changed the calculus."); James Parrinello, Arbitration at the Tipping Point: Challenging Claim-Suppressing Arbitration Clauses, 65 HASTINGS L.J. 1441 (2014) (arguing that companies have a strong incentive to include class action waivers in their contracts with consumers).

242 In Nitsch v. DreamWorks Animation SKG Inc., for instance, the court granted a motion to compel arbitration of Nitsch's class action antitrust claim against his employer for conspiring with its competitors to enter into "no-hire" agreements, on the theory that Nitsch's employment agreement required arbitration and his antitrust claims arose out of his employment. No. 14-CV-4062-LHK, 2015 WL 1886882, at *910 (N.D. Cal. Apr. 24, 2015). Notably, the court declined to compel arbitration of his claims against other defendants in the conspiracy, but the effect was still to send part of his (and therefore the class's) antitrust claims to arbitration. Id. at *10; see also In re Cox Enters. Inc. Set-Top Cable Television Box Antitrust Litig., No. 12-ML-2048-C, 2014 WL 104964, at *2-3 (W.D. Okla. Jan. 9, 2015) (granting motion to arbitrate class antitrust claim), appeal docketed, No. 15-6076 (10th Cir. Apr. 22, 2015).

243 See Stolt-Nielsen, 559 U.S. at 697 n.10 (Ginsburg, J., dissenting) (citing cases).

244133 S. Ct. 2304, 2311 (2013). 
clauses commonly contain confidentiality requirements. ${ }^{245}$ This purported advantage of arbitration is quite disadvantageous for antitrust plaintiffs, however, because it can prevent cost sharing or even information sharing among the victims of antitrust violations. For example, the agreement at issue in Italian Colors precluded the plaintiffs from even informally arranging among themselves to pay for a common expert report that each could use in his or her individual arbitration proceeding. ${ }^{246}$ Such consolidation would be absolutely necessary in the absence of class actions - which the contract also explicitly prohibited-because no individual victim alone could afford to pay for an expert report. ${ }^{247}$ As Justice Kagan noted in dissent, the agreement imposed by American Express "cut[] off not just class arbitration, but any avenue for sharing, shifting, or shrinking necessary costs. [American Express] has put Italian Colors to this choice: Spend way, way, way more money than your claim is worth, or relinquish your Sherman Act rights." ${ }^{248}$ Despite the proffered efficiency justifications for arbitration, this provision was designed to create inefficiency in order to make claims against the defendant cost-prohibitive.

Further, while an antitrust defendant who loses a lawsuit in court to one plaintiff will ordinarily be collaterally estopped from contesting the issues decided in the first case in a subsequent suit, ${ }^{249}$ offensive nonmutual collateral estoppel does not necessarily apply to arbitration proceedings. Some courts have held that parties are not bound by the results of prior arbitrations in a subsequent arbitration unless they agree to be so bound. ${ }^{250}$ Moreover, even if parties were formally bound with respect to issues decided by prior arbitrators, practical considerations may make the application of collateral estoppel in this context unlikely. Since arbitrations are confidential, a plaintiff may never find out about the outcome of a prior arbitration. ${ }^{251}$ And even if a plaintiff seeks to learn of the prior case in

245 Philip Rothman, Pssst, Please Keep It Confidential: Arbitration Makes It Possible, DisP. RESOL. J., Sept. 1994, at 69, 70-71.

246133 S. Ct. at 2316 (Kagan, J., dissenting) ("The agreement also disallows any kind of joinder or consolidation of claims or parties. And more: Its confidentiality provision prevents Italian Colors from informally arranging with other merchants to produce a common expert report.").

247 See supra notes 236-38 and accompanying text.

248 Italian Colors, 133 S. Ct. at 2316 (Kagan, J., dissenting).

249 See Parklane Hosiery Co. v. Shore, 439 U.S. 322, 332-33 (1979).

250 See, e.g., LaSalla v. Doctor's Assocs., Inc., 898 A.2d 803, 812 (Conn. 2006) ("In the absence of a specific contractual provision governing the issue, for which the parties are certainly free to bargain, arbitrators are not required to apply claim preclusion; rather, they are free to apply or reject the doctrine to the extent that they deem it appropriate because the parties have bargained for their judgment.").

251 James M. Westerlind, The Preclusive Effect of Arbitration Awards, MEALEY's LITIG. REP.: REINSURANCE, Aug. 20, 2010, at 1, 6 ("As a practical matter, a non-party to the first arbitration may not know of the resulting award. Most arbitrations are confidential, and only the award itself, which may not include a finding of facts, is usually made a matter of public record when a party moves to confirm. In 
discovery, some kinds of arbitration agreements provide that the results of prior arbitrations do not have to be disclosed. ${ }^{52}$ The result is that not only must each plaintiff bring an arbitration on his or her own, but that each and every plaintiff may have to relitigate the very issues that previous plaintiffs have already proven. The practical effect of such a requirement is to make vindication of antitrust rights even more cost prohibitive, and hence even more unlikely.

To be sure, class actions have their share of problems, and have been abused in various circumstances. ${ }^{253}$ But problems with class actions are not a reason to abolish them altogether in antitrust cases. And even if they should be abolished, it is policymakers rather than self-interested defendants who should make that decision.

\section{Conclusion}

The combination of all of these factors means that as large companies increasingly impose arbitration agreements on antitrust plaintiffs, the effectiveness of antitrust enforcement will decline across every dimensionthe process used, the remedies available, and the ability to consolidate or even rely on related cases. Antitrust rights cannot effectively be vindicated in a world in which all or most antitrust plaintiffs are functionally barred from taking their cases to court. ${ }^{254}$

addition, an arbitration award may never be confirmed if the losing party simply pays, or the prevailing party, owing nothing, chooses to not file a motion for the purpose.").

${ }^{252}$ Id. ('[A]n 'honorable engagement' clause in the parties' arbitration agreement may be relied upon by the panel in a subsequent arbitration to disallow the introduction of a prior arbitration award or to ignore it if it is introduced.").

${ }^{253}$ E.g., Christopher R. Leslie, A Market-Based Approach to Coupon Settlements in Antitrust and Consumer Class Action Litigation, 49 UCLA L. REv. 991, 994 (2002) (explaining that coupon-based class action settlements "illustrate how defendants have structured class action settlements to maximize the gains for the corporate defendant while minimizing any compensation to the class").

254 Arbitration applies only in cases of privity, so in theory there might remain some antitrust plaintiffs that have never done business directly with the defendant and so have not been bound to an arbitration agreement with them. In practice, however, that is unlikely for two reasons. First, courts have been willing to enforce even standard-form arbitration agreements included in clickwrap or shrinkwrap licenses. Mark A. Lemley, Terms of Use, 91 MinN. L. REV. 459, 459-60 (2006) [hereinafter Lemley, Terms of Use]. Therefore, many large retailers may have bound virtually everyone in the country to this new, attenuated form of "contract." Second, and more important, federal antitrust law permits suit only by direct purchasers, Ill. Brick Co. v. Illinois, 431 U.S. 720, 746 (1977), and those direct purchasers are the very ones most likely to have entered into a contract directly with the defendant. For an argument that the direct purchaser rule at least must change after Italian Colors, see Mark A. Lemley \& Christopher R. Leslie, Antitrust Arbitration and Illinois Brick, 100 IowA L. REV. 2115 (2015). 


\section{ANTITRUST ARBITRATION IN A CONCENTRATED MARKET}

The proliferation of antitrust arbitration undermines the antitrust enforcement regime. Market concentration exacerbates the downsides of mandatory arbitration because firms without competitors are more likely to impose onerous terms, such as arbitration clauses, on their customers. Because antitrust violations often occur in concentrated markets-or cause markets to become concentrated - antitrust violators may have more ability to effectively require consumers to waive their rights to litigate as a condition of doing business. When antitrust violators impose arbitration clauses, the premise of mandatory arbitration - that informed consumers voluntarily agree to arbitrate - is not met. Mergers worsen the problem because they can result in a market dominated by a single firm or an oligopoly. In either scenario, the surviving market players will have enhanced their ability to contract around antitrust liability. A single dominant firm may be able to impose onerous terms like mandatory individual arbitration on its customers, and a small number of firms remaining in a concentrated market post-merger will be better able to explicitly or tacitly coordinate the imposition of such arbitration clauses on an industry-wide basis.

In praising the benefits of arbitration - and enforcing arbitration clauses as voluntarily entered into-federal judges implicitly assume a competitive marketplace in which arbitration clauses are freely negotiated between the contracting parties. Historically, private arbitration arose as a dispute resolution mechanism for commercial actors of relatively equal bargaining power. ${ }^{255}$ In enacting the FAA, Congress envisioned scenarios "primarily where merchants sought to resolve disputes of fact, not law, under the customs of their industries, where the parties possessed roughly equivalent bargaining power."256 Equal bargaining power is a consequence of competitive markets - markets in which a seller can turn to many buyers and buyers can purchase from other sellers.

Courts operate as though this model of equal parties agreeing to arbitrate still prevails. For example, the Supreme Court has emphasized the "the consensual nature" of arbitration, noting that both "parties are "generally

255 Leslie, supra note 5; Morris Stone, A Paradox in the Theory of Commercial Arbitration, 21 ARB. J. 156, 162 (1966) ("The founders of the American arbitration movement thought almost exclusively in terms of transactions between parties of approximately equal bargaining power, and of contracts specifically drafted for each occasion.").

256 AT\&T Mobility LLC v. Concepcion, 131 S. Ct. 1740, 1758 (2011) (Breyer, J., dissenting) (citing legislative history of the FAA). Early cases allowing arbitration of antitrust claims involved commercial contracts between firms, not consumer contracts. Scott S. Megregian \& Todd Babbitz, The Use of Mandatory Arbitration to Defeat Antitrust Class Actions, ANTITRUST, Summer 1999, at 63, 66 ("A review of the decided cases shows that almost all arbitration clauses that have been upheld involved negotiated contracts between 'sophisticated' parties. To date, these cases have tended to involve disputes over 'vertical' restraints between manufacturers and distributors."). 
free to structure their arbitration agreements as they see fit." ${ }^{257}$ When enforcing arbitration clauses, courts assume a free, competitive marketplace in which consumers can turn to other sources of the product. ${ }^{258}$ This assumption is critical because the consumers' ability to reject the arbitration clause is dependent on being able to purchase the product from a supplier that does not require consumers to waive their rights to sue in federal court. ${ }^{259}$ Absent that alternative supplier, consumers purchasing the necessities of life have no ability to avoid mandatory arbitration. Courts do not necessarily appreciate the absence of consumer choice. ${ }^{260}$ Economists, too, argue that in competitive markets consumers must be receiving some form of compensation - such as a price discount - for foregoing their right to sue in federal court. ${ }^{261}$ But this assumes that a competitive market exists, that consumers are well-informed about the details of multi-page contracts they may never see, and that consumers have sufficient bargaining power to play suppliers off of each other. Such market conditions do not exist in many industries that impose mandatory arbitration on their customers. ${ }^{262}$

Supporters of mandatory arbitration assume that arbitration clauses are the product of voluntary, informed bargaining. ${ }^{263}$ The chief proponents of the

257 Stolt-Nielsen S.A. v. AnimalFeeds Int'l Corp., 559 U.S. 662, 683 (2010) (quoting Mastrobuono v. Shearson Lehman Hutton, Inc., 514 U.S. 52, 57 (1995)).

258 See, e.g., In re Universal Serv. Fund Telephone Billing Practices Litig., 300 F. Supp. 2d 1107, 1126 n.9 (D. Kan. 2003); Acquaire v. Can. Dry Bottling, 906 F. Supp. 819, 827 (E.D.N.Y. 1995).

259 Buffon \& Wolson, supra note 68, at 35 ("Consumers must also be given an opportunity to reject the agreement, either by walking away from the transaction, returning the product, or in some other way." (citing Ingle v. Circuit City Stores, Inc., 328 F.3d 1165, 1171-72 (9th Cir. 2003))).

260 Id. at 36 n.24 ("Different courts ... have somewhat different views of how much freedom a customer must have to make a meaningful choice.").

261 See Richard H. Thaler \& CASS R. Sunstein, Nudge: IMPROVIng Decisions About HeALTH, WEALTH, AND HAPPINESS 214 (updated ed. 2009) ("So long as there is competition, patients will have to get something for relinquishing their rights. We are confident that if the proposal we are making were adopted, we would both elect to waive the right to sue, and that many of the finest health care providers would offer that option at a real discount.").

262 See, e.g., CONSUMER Fin. Prot. Bureau, ARBitration StUdy $\S 2.3$ ("Seven of the eight largest facilities-based mobile wireless providers $(87.5 \%)$, covering $99.9 \%$ of subscribers, used arbitration clauses in their 2014 customer agreements."); id. ("For storefront payday loan agreements, 83.7\% of lenders covering $98.5 \%$ of storefronts in our sample used arbitration clauses in their agreements from 2013 and $2014 \ldots .$. .. $)$.

263 Stolt-Nielsen S.A. v. AnimalFeeds Int'1 Corp., 559 U.S. 662, 681 (2010) (“"T] certain rules of fundamental importance, including the basic precept that arbitration is a matter of consent, not coercion." (quoting Volt Info. Scis., Inc. v. Bd. of Trs. of Leland Stanford Junior Univ., 489 U.S. 468, 479 (1989))); Gerald Aksen, Arbitration and Antitrust-Are They Compatible?, 44 N.Y.U. L. REV. 1097, 1101 (1969) ("Where parties voluntarily choose arbitration as their method of deciding a potential antitrust problem, their incentive might include the willingness to provide all the necessary books, records and other information so that the arbitral determination will be well-supported by the facts and evidence. If one businessman is clearly profiting by skirting close to the fringes of antitrust violations, it is unlikely that his contract would ever provide for arbitration."); Stephen J. Ware, Arbitration Under Assault: Trial Lawyers Lead the Charge, POL'Y ANALYSIS, Apr. 18, 2002, at 1, 8. 
FAA in the 1920s implicitly assumed competitive markets when they claimed that: "No one is required to make an agreement to arbitrate. Such action by a party is entirely voluntary. ... [The federal arbitration law] is merely a new method for enforcing a contract freely made by the parties thereto." ${ }^{264}$ Some scholars have asserted that, in the context of antitrust arbitration, consumers voluntarily agree to "to forego statutory remedies of treble damages and attorney fees." ${ }^{265}$

These assumptions, however, do not correspond to reality. Arbitration clauses are often imposed on unwilling or unaware consumers. ${ }^{266}$ Contracts of adhesion that include mandatory arbitration provisions are quite common. ${ }^{267}$ The American Safety court argued that antitrust plaintiffs should not lose their day in court because of contracts of adhesion. ${ }^{268}$ In contrast, the Supreme Court does not seem to believe that contracts of adhesion are a problem for consumers with respect to arbitration. ${ }^{269}$ Ironically, the Supreme

264 Julius Henry Cohen \& Kenneth Dayton, The New Federal Arbitration Law, 12 VA. L. REV. 265, 279 (1926)

265 Aksen, supra note 263, at 1110 ("No one is forced to arbitrate; but electing to forego statutory remedies of treble damages and attorney fees should be given serious consideration."). But see FED. TRADE COMM'N, supra note 95, at iv ("Consumers currently have little, if any, choice regarding mandatory pre-dispute arbitration provisions in contracts.").

266 CONSUmer FIn. Prot. Bureau, supra note 262 at $\S 3.2$ (reviewing a study where "of the respondents that specifically stated that they looked to see if their contracts included arbitration clauses (and went on to say that they had never entered into a contract with an arbitration clause), $85 \%$ had, in fact, entered at least one contract with an arbitration clause." (citing Jeff Sovern et al., "Whimsy Little Contracts" with Unexpected Consequences: An Empirical Analysis of Consumer Understanding of Arbitration Agreements 61-62 (St. John's Legal Studies Research Paper Series, Paper No. 14-0009, Oct. 29, 2014), http://ssrn.com/abstract=2516432 [http://perma.cc/B32H-Y9KZ])); FED. TRADE COMM'N, supra note 95 , at 42 . For examples of courts enforcing such standard-form agreements to mandate arbitration of antitrust claims, see Nitsch v. DreamWorks Animation SKG Inc., No. 14-CV-4062-LHK, 2015 WL 1886882, at*9-10 (N.D. Cal. Apr. 24, 2015); Spinelli v. Nat'l Football League, No. 13 Civ. 7398(RWS), 2015 WL 1433370, at*10 (S.D.N.Y. Mar. 27, 2015).

267 See AT\&T Mobility LLC v. Concepcion, 131 S. Ct. 1740, 1750 (2011) ("[T]he times in which consumer contracts were anything other than adhesive are long past."); DOMESTIC POLICY SUBCOMM. MAJORITY STAFF, OVERSIGHT AND GOV'T REFORM COMM., HOUSE OF REPRESENTATIVES, ARBITRATION ABUSE: AN EXAMINATION OF Claims Files OF THE NATIONAL ARbitRATION ForUm 3 (2009) ("Virtually all consumer transactions with large businesses are now subject to pre-dispute, mandatory arbitration clauses."); FED. TRADE COMM'N, supra note 95, at 37; Jessica Silver-Greenberg \& Robert Gebeloff, Arbitration Everywhere, Stacking the Deck of Justice, N.Y. TIMES, Nov. 1, 2015, at A1 ("Over the last few years, it has become increasingly difficult to apply for a credit card, use a cellphone, get cable or Internet service, or shop online without agreeing to private arbitration."). But see Peter B. Rutledge \& Christopher R. Drahozal, "Sticky” Arbitration Clauses? The Use of Arbitration Clauses After Concepcion and Amex, 67 VAND. L. REV. 955 (2014) (finding that franchisors were not switching en masse to arbitration despite Italian Colors).

268391 F.2d 821, 827 (2d Cir. 1968) (" [I]t is also proper to ask whether contracts of adhesion between alleged monopolists and their customers should determine the forum for trying antitrust violations.").

269 See Concepcion, 131 S. Ct. at 1750; Baker \& Stabile, supra note 4, at 405 ("Justice Blackmun's majority opinion [in Mitsubishi] stressed the broad policy of the Federal Arbitration Act and criticized the American Safety rationale for denying arbitration for antitrust claims. First, the majority found 'unjustified' the concern that arbitration would be foisted upon helpless parties to contracts of adhesion- 
Court only seems to care about consent being explicit when it protects corporate defendants from class-wide arbitration. ${ }^{270}$ Yet consumers are forced into arbitration without meaningful consent in clickwrap, shrinkwrap, and even browsewrap contracts they may never see, much less bargain over. ${ }^{271}$ The weaker party is forced to give up the right to sue for antitrust violations in federal court. ${ }^{272}$

Arbitration clauses imposed on consumers through contracts of adhesion are not truly voluntary. ${ }^{273}$ The terms in arbitration agreements may not reflect any bargaining - or true agreement - at all. For example, the agreement at issue in Concepcion authorized AT\&T to unilaterally amend the consumer contract, including the arbitration provision, at its will, which AT\&T did "on several occasions." 274 Some commentators have suggested that it is only natural and expected that arbitration clauses follow the dynamics of contracting in which a more powerful party takes advantage of a less powerful party. ${ }^{275}$ Even if that were true, it is unclear why the fact that we should expect no better should be sufficient reason to allow private arbitration to replace public litigation in antitrust law, which is imbued with the public interest. ${ }^{276}$

When it comes to antitrust arbitration, the lack of meaningful consent becomes a vicious cycle. Antitrust violations eliminate the competition that arbitration supporters assume was present in order to justify enforcing the arbitration clause in the first place. For example, if rivals conspire to fix

such parties could attempt to have the arbitration clause set aside by attacking the validity of the agreement itself." (footnote omitted)).

270 See Stolt-Nielsen S.A. v. AnimalFeeds Int'1 Corp., 559 U.S. 662, 684 (2010) (“[A] party may not be compelled under the FAA to submit to class arbitration unless there is a contractual basis for concluding that the party agreed to do so.").

271 See generally NANCY S. Kim, WRAP CONTRACTS: Foundations AND RAMIFICATIONS (2013) (tracing the history of wrap contracts and discussing their ramifications); Mark A. Lemley, Intellectual Property and Shrinkwrap Licenses, 68 S. CAL. L. REV. 1239 (1995) [hereinafter Lemley, Shrinkwrap Licenses] (discussing arguments for and against shrinkwrap contracts and suggesting modifications to the UCC regarding such contracts); Lemley, Terms of Use, supra note 254, at 459-60 (discussing the elimination of assent as an element of contract law and problems resulting from browsewrap contracts).

${ }^{272}$ Loevinger, supra note 9, at 1091 ("The private parties in antitrust claims are likely to be of unequal economic power and the complainant may have been forced to agree to the arrangement under which arbitration is provided.").

${ }^{273}$ Friedrich Kessler, Contracts of Adhesion-Some Thoughts About Freedom of Contract, 43 Colum. L. REV. 629, 632 (1943); Dempsey, supra note 8, at 284 (“An individual's signature to a contract with a large retail enterprise containing an arbitration clause can hardly mean that the individual has voluntarily relinquished the protection of the courts.").

274 131 S. Ct. at 1744

275 See, e.g., Aksen, supra note 263, at 1102 ("In the vast majority of business life one side has relatively smaller bargaining power. Every small businessman is unequal per se to the mammoth corporations with whom he must trade in order to survive.").

276 See Christopher R. Leslie, Antitrust Law as Public Interest Law, 2 U.C. IRVINE L. REV. 885 (2012). 
prices in violation of Section 1 of the Sherman Act, they could similarly conspire to impose mandatory arbitration with a class action waiver in order to prevent any class action against their antitrust violation. ${ }^{277}$ Supporters of expanding arbitration to include antitrust claims assume that competition will prevent abuse of mandatory arbitration clauses. But antitrust violators will have every incentive to simply expand the subject matter of their conspiracy to include the prevention of competition with respect to mandatory arbitration.

Such an agreement among competitors to impose pro-seller mandatory arbitration terms could itself be an antitrust violation. ${ }^{278}$ In 1930s Paramount Famous Lasky Corp. v. United States, ${ }^{279}$ the Supreme Court condemned movie distributors who jointly agreed to contract only with theaters that agreed to a standard form contract that included an arbitration clause. ${ }^{280}$ The distributor-imposed terms of the standard form arbitration clause were the result of "six years of discussion and experimentation" among rival theaters. ${ }^{281}$ The Supreme Court explained: "It may be that arbitration is well adapted to the needs of the motion picture industry; but when under the guise of arbitration parties enter into unusual arrangements which unreasonably suppress normal competition their action becomes illegal." 282 When a conspiracy to impose arbitration clauses is part and parcel of a larger conspiracy to fix prices or divide markets, the conspirators can effectively prevent their victims from seeking redress in federal court. The antitrust violation in this scenario eliminates the competitive market that champions of mandatory arbitration assume exists.

Like price fixers, illegal monopolists can also impose arbitration clauses in order to prevent antitrust victims from being able to sue for Sherman Act Section 2 violations in federal court. ${ }^{283}$ Because firms with strong bargaining power can impose onerous terms on their business

\footnotetext{
277 See Christopher R. Leslie, Conspiracy to Arbitrate (on file with author).

278 See id.; see also Am. Safety Equip. Corp. v. J.P. Maguire \& Co., 391 F.2d 821, 827 (2d Cir. 1968) (" $[\mathrm{T}]$ he claim here is that the agreement itself was an instrument of illegality ...."); Loevinger, supra note 9 , at 1094 ("In at least two older cases the courts have noted that arbitration, whatever its normal virtues, may be used as part of an arrangement to suppress competition, and that, in such cases, the courts must determine the validity of the arrangements under the antitrust laws before arbitration is appropriate." (citing Paramount Famous Lasky Corp. v. United States, 282 U.S. 30 (1930); Ring v. Spina, 148 F.2d 647 (2d Cir. 1945))).

279282 U.S. 30 (1930).

280 Id. at 37,42 .

281 Id. at 43.

${ }^{282} \mathrm{Id}$.

283 See Finn, supra note 92, at 415 ("An intended monopolist, being frequently in a bargaining position superior to that of his customer and wishing to avoid the stringent requirements of the antitrust laws, could protect himself by imposing an arbitration agreement on his customer.").
} 
partners, ${ }^{284}$ a monopolist could make all sales contingent on the customer's agreement to waive his or her right to sue for an antitrust violation in federal court, or to bring any form of class-wide arbitration. This was essentially what happened in Italian Colors, where merchants alleged that American Express used its power over charge cards to force merchants to accept an illegal tying arrangement. ${ }^{285}$ The very contract that formed the basis of the antitrust violation simultaneously precluded any judicial - or arbitralremedy for that violation. ${ }^{286}$ As Justice Kagan explained in her dissent in Italian Colors:

[The arbitration clause] imposes a variety of procedural bars that would make pursuit of the antitrust claim a fool's errand. So if the arbitration clause is enforceable, Amex has insulated itself from antitrust liability — even if it has in fact violated the law. The monopolist gets to use its monopoly power to insist on a contract effectively depriving its victims of all legal recourse. ${ }^{287}$

By manipulating the terms of a required arbitration agreement, even an illegal monopolist can prevent all class action litigation and class-wide arbitration, making it practically impossible for any of its customers to seek any form of relief for their antitrust injuries, such as monopoly overcharges. As such, the monopolist-imposed arbitration clause is the shield that protects an illegal monopoly from antitrust liability. ${ }^{288}$

It is unlikely that Congress intended that "contracts of adhesion between alleged monopolists and their customers should determine the forum for trying antitrust violations." ${ }^{289}$ New York's highest court observed during the American Safety era:

284 Albert Choi \& George Triantis, The Effect of Bargaining Power on Contract Design, 98 VA. L. REV. 1665, 1680-86 (2012); see also George Padis, Note, Arbitration Under Siege: Reforming Consumer and Employment Arbitration and Class Actions, 91 TEX. L. REV. 665, 686-87 (2013) ("Professors Choi and Triantis persuasively argue that sellers with oppressive bargaining power alone can impose inefficiently one-sided terms even between sophisticated parties, because sellers with superior bargaining power can screen buyers to reduce the quality of nonprice terms to maximize profit in a way that is not socially optimal.").

285133 S. Ct. 2304, 2308 (2013).

286 See id. at 2313 (Kagan, J., dissenting) ("Here is the nutshell version of this case, unfortunately obscured in the Court's decision. The owner of a small restaurant (Italian Colors) thinks that American Express (Amex) has used its monopoly power to force merchants to accept a form contract violating the antitrust laws. The restaurateur wants to challenge the allegedly unlawful provision (imposing a tying arrangement), but the same contract's arbitration clause prevents him from doing so.").

287 Id.

288 Id. at 2314 (arguing that the necessity of a rule against contracts that operate as waivers of federal rights "is nowhere more evident than in the antitrust context" since "[w]ithout the rule, a company could use its monopoly power to protect its monopoly power, by coercing agreement to contractual terms eliminating its antitrust liability.").

289 Am. Safety Equip. Corp. v. J.P. Maguire \& Co., 391 F.2d 821, 827 (2d Cir. 1968). 
[T]hrough the use of economic power and contracts of adhesion, containing broad arbitration clauses, antitrust violators may be able to insulate their transgressions of the antitrust law from judicial scrutiny. The opportunity for abuse is apparent. Under various guises, an industry, while nominally assuring obedience to the State's antitrust law, may in reality be establishing and enforcing entirely unacceptable practices. ${ }^{290}$

In concentrated markets where firms use contracts of adhesion to impose arbitration clauses, courts should be most wary of antitrust claims being shunted off to private, confidential arbitration. Current trends, however, indicate that courts are not likely to take action to meaningfully limit the scope of adhesive antitrust arbitration agreements. The final Part of this Article therefore proposes a nonjudicial solution to this increasingly important problem.

\section{AdDRESSING THE PROBLEM OF ANTITRUST ARBITRATION THROUGH MERGER ENFORCEMENT}

Antitrust arbitration has created problems and issues that were unanticipated by the Congress that enacted the FAA. The Supreme Court has expanded the scope of arbitration in a manner that undermines the ability of antitrust law to protect consumers. Most government actors seem illequipped or unlikely to address the problems outlined in Part II. The judiciary is the branch that created the overreaching version of arbitration. Some members of Congress have responded to the pro-arbitration opinions of the Supreme Court by proposing the Arbitration Fairness Act, which would prevent enforcement of some predispute mandatory arbitration clauses in consumer contracts. ${ }^{291}$ The likelihood of successful legislative action, however, is uncertain at best. In contrast, the Executive Branchthrough the Federal Trade Commission and the Department of Justice's Antitrust Division — could address the particular issue of antitrust arbitration immediately.

Public and private enforcement of antitrust laws work in tandem. ${ }^{292}$ Antitrust lawsuits brought by private plaintiffs have been a critical part of

\footnotetext{
290 Aimcee Wholesale Corp. v. Tomar Prods., Inc., 237 N.E.2d 223, 227 (N.Y. 1968).

291 See, e.g., Press Release, Sen. Al Franken, U.S. Cong. (Apr. 29, 2015), http://www.franken. senate.gov/files/documents/150429_AFAOnePager.pdf [http://perma.cc/WG8U-ZVHY].

292 See generally Robert H. Lande \& Joshua P. Davis, Comparative Deterrence From Private Enforcement and Criminal Enforcement of the U.S. Antitrust Laws, 2011 BYU L. REV. 315 (evaluating the deterrent effect of private antitrust litigation and finding it a complement to the deterrent effects of public enforcement). But see Frank H. Easterbrook, The Limits of Antitrust, 63 TEX. L. REV. 1, 33-39 (1984) (arguing that we should limit private antitrust enforcement because the cost of false positives outweighs the cost of false negatives). As one of us has argued:

Judge Easterbrook could speak in 1984 of the asymmetry between false positives and false negatives, but the antitrust law he was talking about simply doesn't exist anymore. Courts in the
} 
the American antitrust regime for over a century. ${ }^{293}$ Antitrust class action litigation is particularly important. ${ }^{294}$ Yet Italian Colors thwarts attempts to bring both individual and class-wide actions against antitrust violators. Mergers may heighten the need for private as well as government oversight. The problems of antitrust arbitration, detailed in Part II, are magnified in a post-merger context for the reasons we explained in Part III. These merged firms should receive greater scrutiny, but mandatory arbitration of antitrust claims means that these firms - which present the greatest antitrust riskscan evade meaningful judicial scrutiny.

In this Part, we propose a solution to the growing problem of antitrust arbitration.

\section{A. Conditional Approval of Proposed Mergers}

Mergers among actual or potential competitors increase market concentration. Concentrated markets tend to heighten antitrust risks in various ways, including facilitating monopolization by a dominant firm and making it easier for the remaining firms in the market to collude. ${ }^{295}$ Because of these risks, the Hart-Scott-Rodino Act notes that the Antitrust Division and the Federal Trade Commission share responsibility for the review and preclearance of mergers that reach a size specified by the Act. ${ }^{296}$ At the conclusion of its review, the government can decide to not challenge the merger at all, to attempt to block the merger altogether, or to negotiate certain conditions designed to reduce the risk of harm to competition..$^{297}$

last three decades have dismantled every per se rule applied to vertical conduct, limited the per se rule in horizontal conspiracies in a variety of ways, made it harder for plaintiffs to infer conspiracies, all but eliminated predatory-pricing claims, and substantially restricted the role of monopolization cases. Win rates for antitrust plaintiffs in at least one industry hover below $15 \%$, and court rules make it harder and harder for antitrust plaintiffs to show standing to sue to enforce the laws that remain. We have no doubt that antitrust at one time was skewed toward over-enforcement, but today if there is any bias it is in the opposite direction.

Stacey L. Dogan \& Mark A. Lemley, Antitrust Law and Regulatory Gaming, 87 TEX. L. REV. 685, 70001 (2009) (footnotes omitted).

293 See Joshua P. Davis \& Robert H. Lande, Defying Conventional Wisdom: The Case for Private Antitrust Enforcement, 48 GA. L. REV. 1 (2013) (examining the virtues of private antitrust litigation in light of public antitrust enforcement); Robert H. Lande \& Joshua P. Davis, Benefits From Private Antitrust Enforcement: An Analysis of Forty Cases, 42 U.S.F. L. REV. 879 (2008) (evaluating private antitrust litigation and finding it an important complement to public enforcement); D. Daniel Sokol, The Strategic Use of Public and Private Litigation in Antitrust as Business Strategy, 85 S. CAL. L. REV. 689 (2012) (same).

294 See supra notes 234-39 and accompanying text.

295 See U.S. DeP'T OF Justice \& Fed. Trade COMM’N, Horizontal MERGER Guidelines $\S \S 6-7$ (2010), http://www.justice.gov/atr/public/guidelines/hmg-2010.pdf [http://perma.cc/8P8L-QTX4].

296 15 U.S.C. $\S 18 \mathrm{a}$ (2012).

297 Premerger Notification and the Merger Review Process, FED. TRADE COMM'N, https:/www.ftc.gov/tips-advice/competition-guidance/guide-antitrust-laws/mergers/premergernotification-and-merger [https://perma.cc/YWJ8-VV5J ]. 
When the government allows a merger subject to conditions, those conditions can take a variety of forms. One common form of condition is structural: the government might force the merging parties to divest or sell off certain assets or business units in order to preserve competition in particular markets. ${ }^{298}$ Those divestiture conditions in turn come in two flavors. Sometimes the parties and the government have already identified a buyer and require the transaction to happen before or immediately after the merger is approved. ${ }^{299}$ Such a divestiture is relatively easy to monitor.

Other conditional merger approvals mandate a "post-order" divestiture: a promise to sell specified assets at some point in the future assuming a suitable buyer can be found who is willing to pay a suitable price. ${ }^{300}$ The agencies typically enforce post-order divestitures by requiring the merging parties to hold themselves separate in certain respects during the merger process so that the separate assets can later be sold. ${ }^{301}$ Post-order divestiture conditions are theoretically binding on the merging entities. But in fact, effective enforcement is rare. The agencies may reserve the power to impose a "crown jewel" provision that requires divestiture of certain key assets in a merger in the event the merged entity fails to divest the agreed assets, ${ }^{302}$ but they rarely do so. As Gelfand and Ewing observe, "[c]rown jewel provisions are only rarely included in consent decrees by either agency and, even when they are included, they are almost never invoked." ${ }^{303}$ They find only two examples in this century of enforcement of such a provision, one by the FTC and one by the DOJ. ${ }^{304}$ Post-order divestiture conditions, then, are difficult for the agencies to enforce.

\footnotetext{
298 See Antitrust Div., U.S. DeP’T of Justice, Antitrust Division Policy Guide to Merger REMEDIES 23-25 (2011), http://www.justice.gov/atr/public/guidelines/272350.pdf [http://perma.cc/ DT4K-UWMM] (discussing structural and behavioral conditions in merger enforcement).

${ }^{299} I d$. Gelfand and Ewing refer to these as "buyer up front" divestitures. David Gelfand \& Elaine Ewing, "Be Careful What You Wish for": U.S. Government Enforcement of Merger Consent Decrees, 58 ANTITRUST BULL. 225, 226-27 (2013).

300 Gelfand \& Ewing, supra note 299, at 227.

$301 \mathrm{Id}$.

302 See Frequently Asked Questions About Merger Consent Order Provisions, Fed. TRADE COMM'N, https://www.ftc.gov/tips-advice/competition-guidance/guide-antitrust-laws/mergers/merger-faq\#Crown \%20Jewels [https://perma.cc/TZQ5-A2GT]. For an example, see Final Judgment at 10-16, United States v. Monsanto Co., No. 1:07-cv-00992 (D.D.C. Nov. 6, 2008), http://www.justice.gov/atr/cases/f239400/239476.pdf [http://perma.cc/A377-X2NJ]

303 Gelfand \& Ewing, supra note 299, at 235.

304 Id. at 235-36 (citing Order Reopening and Modifying Order, Hoechst AG, No. C-3919 (F.T.C. Nov. 22, 2002), https://www.ftc.gov/sites/default/files/documents/cases/2002/12/hoechsmod.htm [https://perma.cc/4WC7-UH2T]; Press Release, Dep't of Justice, Justice Department Requires Mittal Steel to Divest Sparrows Point Steel Mill (Feb. 20, 2007), http://www.justice.gov/ archive/atr/public/press_releases/2007/221503.pdf [http://perma.cc/NL2K-ZAU7]).
} 
A second type of merger condition is behavioral. Rather than requiring the company to sell assets, the antitrust agencies will often require the merged company to agree to behave (or to refrain from behaving) in certain ways. Merged companies might have to agree to license their intellectual property to others, ${ }^{305}$ to agree not to discriminate in business deals, ${ }^{306}$ or to restrict the flow of information between business units in the merged company. ${ }^{307}$ These sorts of conditions are less common than structural conditions such as asset divestiture, but they are still regularly imposed, and the Antitrust Division has increasingly relied on such remedies. ${ }^{308} \mathrm{We}$ conducted a review of every merger consent decree entered into between 1996 and 2013. ${ }^{309}$ Of the 403 FTC and Antitrust Division merger consent decrees during this period, 124 included conduct conditions as well as divestiture. ${ }^{310}$

Conduct conditions are much harder to enforce, because the conduct being prohibited or required is much less visible to the outside observer than is the sale or nonsale of a division of a company. The antitrust enforcement agencies will sometimes place a monitor within the company to ensure compliance, ${ }^{311}$ and they have the power to ask the merged firm to produce information they can use to gauge compliance. ${ }^{312}$ But even with the assistance of a monitor it is hard to know whether, for instance, information

305 See, e.g., United States v. Google Inc., No. 1:11-cv-00688-RLW, at 13-21 (D.D.C. Oct. 5, 2011), http://www.justice.gov/atr/cases/f275800/275897.pdf [http://perma.cc/5C47-NEE3]; Silicon Graphics, 120 F.T.C. $928,936-38$ (1995).

306 See, e.g., United States v. Comcast Corp., No. 1:11-cv-00106-RJL, at 19-20 (D.D.C. June 29, 2011), http:/www.justice.gov/atr/cases/f272600/272610.pdf [http://perma.cc/7DP4-K6EZ]; United States v. Ticketmaster, No. 1:10-cv-00139-RMC, at 19-21 (D.D.C. July 30, 2010), http://www.justice.gov/atr/cases/f260900/260909.pdf [http://perma.cc/8P3W-RM99].

307 See, e.g., The Coca-Cola Co., 150 F.T.C. 520, 534-39 (2010).

308 Compare ANTITRUST DIV., U.S. DEP'T OF JUSTICE, supra note 299 (emphasizing the desirability of behavioral remedies), with ANTITRUST Div., U.S. DEP'T OF JUSTICE \& FED. TRADE COMM'N, 1992 MERGER GUIDELINES, https://www.ftc.gov/sites/default/files/attachments/merger-review/hmg.pdf [https://perma.cc/GN64-VQKR] (focusing on market structure).

309 Research on file with authors.

310 Divestiture deals can also have behavioral components, as when a merged company agrees to spin off a division while continuing to provide services or a supply of goods to that division. See, e.g., Decision and Order at 11-16, W. Dig. Corp., No. C-4350 (F.T.C. Mar. 5, 2012), https://www.ftc.gov/sites/default/files/documents/cases/2012/03/120305westerndigitaldo.pdf [https:// perma.cc/7CH3-9UXS]. We included a decree in the 124 conduct-related decrees if it had significant conduct-related conditions, even if it also included structural remedies such as divestiture.

311 The Microsoft settlement and the Apple eBooks judicial decree both involved neutral monitors placed inside the company to report on the company's compliance with the injunction. See Final Judgment at 9-13, United States v. Microsoft Corp., No. Civ. A. 98-1232 (CKK) (D.D.C. Nov. 12, 2002), http://www.justice.gov/atr/cases/f200400/200457.pdf [http://perma.cc/76WK-P499]; Final Judgment at 10-14, United States v. Apple, Inc., No.1:12-cv-02826-DLC (S.D.N.Y. Sept. 5, 2013), http://www.justice.gov/atr/cases/f300500/300510.pdf [http://perma.cc/JN32-RMXK]

312 Supra note 311. 
is being shared informally between employees in different divisions of the same company. Our study of all 403 merger consent decrees that imposed ongoing conditions found only eleven cases in which the government sought to enforce a provision of a consent decree, and five of those eleven involved divestiture agreements. While it is impossible to know how many times merged entities violated a consent decree without being caught, or how many times the government detected a violation and resolved the issue informally, actual enforcement appears to be rare ${ }^{313}$ and limited to the most egregious violations of a consent decree. ${ }^{314}$

Even less likely to be enforced are representations made by the merging parties in an effort to persuade the agencies to approve a merger. Airlines, for instance, often make representations that they will continue or even expand a target's hub when they merge with that target. But it doesn't necessarily happen. American Airlines won approval for its acquisition of TWA, for instance, by saying it intended to shift more flights to TWA's St. Louis hub to relieve congestion at its other hubs. ${ }^{315}$ But it made no legally binding commitment to do so, and instead American Airlines soon pulled most of its flights out of St. Louis, ${ }^{316}$ with the result that the merger eliminated a competitor but did not otherwise make American's route structure more efficient. United Airlines did something similar in Cleveland after buying Continental Airlines, ${ }^{317}$ as did American Airlines in Pittsburgh after buying US Airways. ${ }^{318}$ Outside the airline industry, Oracle has repeatedly purchased competitors, including PeopleSoft and Sun Microsystems, ostensibly for the value of their software, and justified the purchases on the ground that it would not reduce software options for

313 See Gelfand \& Ewing, supra note 299, at 237 ("Because investigations into potential consent decree violations are nonpublic, it is difficult to gauge the frequency with which these provisions are invoked. Requests from the agencies for the production of information or documents are quite common, although it is somewhat rare for formal process to be invoked.”)

314 Id. at 239 ("There are only a handful of recent cases in which formal enforcement action was taken, and examining these cases highlights the fact that violations formally enforced by the agencies usually are flagrant .....").

315 See Kyle DiGangi, Note, Cutting the Financial Fat from the Failing Firm Defense: Refocusing the Failing Firm Defense on Antitrust Law, 86 ST. JOHN's L. REV. 277, 298 (2012); Robert Schoenberger, End of TWA in 2001 Hurt Hub in St. Louis As American Airlines Focused on Bigger Airports, Cleveland.COM (May 10, 2010), http://www.cleveland.com/business/index.ssf/2010/05/ st_louis_shrunk_by_american_ai.html [http://perma.cc/FM97-FSLK].

316 See Schoenberger, supra note 315.

317 See Ben Mutzabaugh, United Airlines Axing Its Hub in Cleveland, USA TODAY (Feb. 2, 2014), http://www.usatoday.com/story/todayinthesky/2014/02/01/united-airlines-axing-its-hub-incleveland/5139385/ [http://perma.cc/UA9V-6R9A].

318 See Ben Mutzabaugh, Loss of US Airways Facility a 'Bitter Pill' for Pittsburgh, USA TODAY (Jan. 28, 2014), http://www.usatoday.com/story/todayinthesky/2014/01/28/loss-of-us-airways-facility-abitter-pill-for-pittsburgh/4969169/ [http://perma.cc/WL6Z-EN85]. 
consumers, ${ }^{319}$ only to reduce support for that software once the merger went through. ${ }^{320}$ Comcast failed to adhere to the promises it made to antitrust regulators in acquiring NBC Universal, a fact that came out only when it sought to acquire Time Warner Cable, prompting scrutiny of its record of compliance. ${ }^{321}$ Whether or not these were good business decisions, they reflect the inability of regulatory agencies to bind merging firms to their claims about the economic effects of their mergers.

\section{B. Negotiated Abandonment of Mandatory Arbitration for Antitrust Claims as a Condition of Merger Approval}

Mergers, then, can risk harm to competition. The antitrust agencies can prevent that harm by blocking a merger altogether, and sometimes they do so. But more commonly they seek a less intrusive path-approving the merger subject to conditions designed to improve competition. And many of those conditional approvals impose behavioral rather than structural conditions, again in a laudable attempt to be less intrusive on the operation of the merged firm. Because the agencies have only a limited ability to police and enforce those behavioral conditions, however, private antitrust enforcement becomes even more important when mergers increase market concentration. And yet, as we have seen, the very fact of that increased market concentration, combined with Italian Colors, makes it all too easy for firms in concentrated markets to preclude effective private antitrust enforcement by using a standard for contract to deny antitrust victims access to federal courts.

\footnotetext{
319 See, e.g., Jennifer Arlen, Regulating Post-Bid Embedded Defenses: Lessons From Oracle Versus PeopleSoft, 12 HARV. NeGOT. L. REV. 71, 71-72 (2007) (“Oracle's bid threatened PeopleSoft's value by undermining its ability to enter into long-run relational contracts with new customers who were worried that Oracle would breach PeopleSoft's long-run implicit contracts with them. PeopleSoft's managers were able to preserve PeopleSoft's value by quickly and unilaterally adopting a Customer Assurance Program (CAP) designed to ensure that Oracle honored PeopleSoft's implicit commitments.").

${ }^{320}$ See Order Granting-in-Part Motion to Dismiss and Granting Motion to Strike at 12-13, Oracle Am., Inc. v. Terix Comput. Co., No. 5:13-cv-03385-PSG, 2014 WL 5847532, at *6-7 (N.D. Cal. Nov. 7, 2014) (allowing antitrust claims to proceed based on allegations Oracle cut support for Sun's Solaris operating system after acquiring Sun); Alorie Gilbert, Oracle to PeopleSoft: The Pink Slip's in the Mail, CNET (Jan. 14, 2005, 11:50 AM), http://news.cnet.com/Oracle-to-PeopleSoft-The-pink-slips-in-themail/2100-1014_3-5536612.html [http://perma.cc/6WK5-AF6N] (describing Oracle cutting more than half of the PeopleSoft workforce less than a year after the merger); Ahmed Limam, Dead Software Walking: PeopleSoft 7 Years After Its Acquisition by Oracle, AHMED's UNIVERSE (Sept. 17, 2012), http://ahmedsuniverse.blogspot.com/2012/09/dead-software-walking-peoplesoft-7.html [http://perma.cc/69YT-E68M].

321 See Comcast Was So Incredibly Full of Crap During Its Merger Sales Pitch, the Government Is Considering Additional Punishment, TECHDIRT (June 2, 2015, 6:07 AM), http://www.techdirt.com/articles/20150601/09042031170/comcast-was-s-incredibly-full-crap-duringmerger-sales-pitch-government-is-considering-additional-punishment.shtml [http://perma.cc/TAU7CHXU].
} 
Fortunately, there is a simple, if partial, solution to the problem of ineffective private enforcement of the antitrust laws after Italian Colors. We suggest that the antitrust enforcement agencies tasked with approving mergers should approve mergers subject to the condition that the merged entity promise not to impose or enforce predispute arbitration provisions on its customers. ${ }^{322}$ The government could elect to apply this policy more or less broadly depending on the circumstances. Agencies applying this policy in its most expansive form could prevent the imposition of any predispute arbitration agreement on customers. Doing so would be consistent with the problems with arbitration of consumer contracts we noted above, which are not limited to mandatory arbitration of antitrust disputes. Under a more focused application, the agencies could require that merging firms agree not to impose class action waivers on their consumers. The narrowest application would, at a minimum, impose a condition preventing the merged firm from imposing predispute arbitration on antitrust disputes with customers. ${ }^{323}$

There are several reasons to use the merger approval process to impose restrictions on predispute mandatory arbitration clauses. This is a decision point when government regulators are already examining the merging parties and the markets they are operating in. Antitrust officials at this juncture have leverage over the firms seeking to merge. Imposing arbitration limitations on merging firms is appropriately tailored to the problems with mandatory predispute arbitration agreements. As we have seen, arbitration agreements are most problematic when they are imposed in a standard-form contract on consumers who lack equal bargaining power, when they restrict class actions that make it possible to vindicate important public rights that would otherwise go unrepresented, and when there is no effective competition over contract terms.

Each of those circumstances is likely to be present for standard-form terms that preclude antitrust and other class actions in concentrated markets. Consumers are unlikely to be able to read, much less negotiate, the terms to which they are being bound. ${ }^{324}$ Considerable evidence suggests that virtually

\footnotetext{
322 Our proposal applies only to predispute arbitration agreements. Mandatory agreements of this sort, often included in standard-form contracts, create the sort of problems we discussed above. Once a dispute has arisen, by contrast, an agreement to arbitrate would no longer be coercive and the disputing parties should be free to resolve that dispute in any way they jointly decide to, including arbitration and mediation.

323 If antitrust claims are non-arbitrable, arbitration can still proceed on non-antitrust claims. See W. Int'1 Media Corp. v. Johnson, 754 F. Supp. 871, 873 n.2 (S.D. Fla. 1991).

The duration of the condition - including whether it should be subject to a sunset provision - is an issue for another day.

324 On the fictional nature of assent in modern shrink-, click-, and browsewrap contracts, see generally KIM, supra note 271; Lemley, Shrinkwrap Licenses, supra note 271; Lemley, Terms of Use, supra note 254, at 459-60; Michael J. Madison, Legal-Ware: Contract and Copyright in the Digital Age,
} 
no one reads standard-form terms included in clickwrap and browsewrap contracts. ${ }^{325}$ And even if they did read them, they are unlikely to be able to negotiate those terms; 326 they are always provided in "take it or leave it" form. ${ }^{327}$ Nonetheless, courts tend to enforce those contracts, even when they impose arbitration clauses. ${ }^{328}$

Conditioning merger approval on not imposing mandatory arbitration clauses in their contracts with customers would facilitate effective private antitrust enforcement. Without class actions, relatively long statutes of limitations, attorneys' fees, and treble damages, private antitrust actions are not cost effective for many plaintiffs. That is particularly true of consumers, the group antitrust law purports to care the most about. Consumers are a diffuse group, and each individual consumer is unlikely to have enough at stake to bring an antitrust claim, particularly if they cannot recover their attorneys' fees even if they succeed. That is also true of small business customers. The individual named plaintiff in Italian Colors, for instance, suffered less than $\$ 50,000$ in harm, far too little to spend the over $\$ 1$ million it would take to bring an antitrust case as an individual arbitration. Each individual plaintiff's loss may be relatively small, but the cost of American Express's anticompetitive conduct was, of course, not limited to the harm suffered by a single plaintiff. The collective harm to the groups of small businesses affected might well have ranged into the billions of dollars, a

67 Fordham L. REV. 1025, 1049-54 (1998); Jason Kuchmay, Note, ProCD, Inc. v. Zeidenberg: Section 301 Copyright Preemption of Shrinkwrap Licenses - A Real Bargain for Consumers?, 29 U. TOL. L. REV. 117, 137-46 (1997); Kell Corrigan Mercer, Note, Consumer Shrink-Wrap Licenses and Public Domain Materials; Copyright Preemption and Uniform Commercial Code Validity in ProCD v. Zeidenberg, 30 Creighton L. Rev. 1287, 1296-97 (1997); Apik Minassian, Note, The Death of Copyright: Enforceability of Shrinkwrap Licensing Agreements, 45 UCLA L. REV. 569, 574-83 (1997); Robert J. Morrill, Comment, Contract Formation and the Shrink Wrap License: A Case Comment on ProCD, Inc. v. Zeidenberg, 32 New Eng. L. Rev. 513, 537-50 (1998); Christopher L. Pitet, Comment, The Problem with "Money Now, Terms Later": ProCD, Inc. v. Zeidenberg and the Enforceability of "Shrinkwrap" Software Licenses, 31 Loy. L.A. L. REV. 325, 345-47 (1997); Stephen P. Tarolli, Comment, The Future of Information Commerce Under Contemporary Contract and Copyright Principles, 46 AM. U. L. REV. $1639,1647-48$ (1997).

325 See, e.g., Yannis Bakos et al., Does Anyone Read the Fine Print? Consumer Attention to Standard-Form Contracts, 43 J. LEGAL STUD. 1, 22 (2014).

326 See FED. TRADE COMM'N, supra note 95, at 42-43.

327 Lemley, Shrinkwrap Licenses, supra note 271, at 1288-90.

328 See, e.g., Nicosia v. Amazon.com, Inc., 84 F. Supp. 3d 142 (E.D.N.Y. 2015); Ekin v. Amazon Servs., LLC, 84 F. Supp. 3d 1172 (W.D. Wash. 2014); Tompkins v. 23andMe, Inc., 5:13-cv-05682-LHK (N.D. Cal. June 25, 2014); Briceño v. Sprint Spectrum, L.P., 911 So. 2d 176, 178 (Fla. Dist. Ct. App. 2005). But other courts have put procedural limits on the enforceability of arbitration clauses that do not give consumers reasonable notice of their terms. See, e.g., Savetsky v. Pre-Paid Legal Servs., Inc., No. 3:14-cv-03514-SC (N.D. Cal. Feb. 12, 2015); Knutson v. Sirius XM Radio Inc., 771 F.3d 559, 569 (9th Cir. 2014); Nguyen v. Barnes \& Noble Inc., 763 F.3d 1171, 1176-79 (9th Cir. 2014); see also Friedman v. Guthy-Renker LLC, 2:14-cv-06009-ODW (AGRx) (C.D. Cal. Feb. 27, 2015) (holding an arbitration clause in a browsewrap agreement unenforceable against one user, but enforceable against another, based on a change in the placement of the "terms and conditions" link). 
massive harm with implications for society at large that was essentially immunized from suit by a form contract's bar on class-wide arbitration.

One possible counterargument is that market forces will achieve the same end point - that is, a world without socially inefficient arbitration agreements. Some have argued that firms will compete on contract terms just as they do on price, driving those terms to efficiency over the long run. ${ }^{329}$ In theory, then, customers who oppose arbitration terms could refuse to do business with firms that impose those terms. If enough customers did so, market pressure might force others to drop those terms. We are skeptical that that sort of competition actually happens. Empirical research has shown little competition on terms, ${ }^{330}$ perhaps because no one reads those terms and therefore no one knows that they might differ. ${ }^{331}$

Even if there were such competition in some markets, however, HartScott-Rodino review is uniquely well positioned to provide relief in the markets where it is least likely to be true. Competition on arbitration terms would require, at a minimum, a competitive market in which otherwise equivalent products were differentiated only on the consumer friendliness of their contract terms. The antitrust agencies review mergers only when they reach a certain size, and they are likely to challenge those mergers or impose conditions on approval only when the risk of undue market concentration is substantial. ${ }^{332}$ Therefore, challenging predispute arbitration agreements during merger review will enable the government to target arbitration agreements imposed in those highly concentrated market conditions most likely to incubate anticompetitive behavior.

One effect of having the antitrust agencies impose such a limitation is that not all companies - and indeed not all dominant firms - will be subject to the restriction. While this may seem unfair, there is a certain equity to it. It is only the companies who seek to merge in already-concentrated markets that will face this limitation, and those are the very companies we should most want to be subject to the full scrutiny of the antitrust laws. It seems reasonable that a company that asks for an exemption from government

329 See, e.g., Frank H. Easterbrook, Contract and Copyright, 42 Hous. L. REV. 953, $968-69$ (2005); Robert A. Hillman \& Maureen O'Rourke, Defending Disclosure in Software Licensing, 78 U. CHI. L. REV. 95, 105-06 (2011); Robert A. Hillman \& Jeffrey J. Rachlinski, Standard-Form Contracting in the Electronic Age, 77 N.Y.U. L. REV. 429, 441-45 (2002).

330 E.g., Florencia Marotta-Wurgler, Are "Pay Now, Terms Later" Contracts Worse for Buyers? Evidence From Software Licensing Agreements, 38 J. LEGAL STUD. 309 (2009) (finding that terms actually provided to customers - on which companies could theoretically compete - are no more favorable than terms not even provided until after the deal is done); Florencia Marotta-Wurgler, Will Increased Disclosure Help? Evaluating the Recommendations of the ALI's "Principles of the Law of Software Contracts," 78 U. CHI. L. REV. 165 (2011).

331 See Bakos et al., supra note 325 , at 5.

332 See U.S. DeP'T OF JusticE \& Fed. TRADE COMM’N, supra note 295, at $§$ 2.1.3. 
antitrust scrutiny for its merger should have to forego effective immunity from private antitrust enforcement going forward. ${ }^{333}$

The fact that only some companies are subject to this condition offers a sort of natural experiment. If antitrust enforcement is effective even absent class actions and access to the courts, it should not matter whether a company is subject to such a condition. But if, as we argue here, effective private antitrust enforcement requires access to the courts and the strong remedial mechanisms of antitrust, we should expect varying patterns of private enforcement against companies that can block antitrust lawsuits and against those that forego the ability to do so. If the agencies chose to apply our proposal more broadly - imposing this condition not only with respect to antitrust claims but to class actions more generally—we would have a similar window into the effectiveness of class actions as a whole. Further, the uneven application of the rule may have an interesting side benefit: companies subject to the restriction on arbitration will have an incentive to make the best of their situation by promoting the more consumer-friendly nature of their terms and conditions. ${ }^{334}$ While we are skeptical that there is competition on terms and conditions now, if it is possible to prompt such competition, the best way to do so is by giving some companies no choice but to offer more consumer-friendly terms and hope that they can get some mileage out of advertising that fact.

To be sure, these advantages are partial. Because the imposition of mandatory arbitration clauses to ban class actions undermines effective private antitrust enforcement, the best possible alternative would be to forbid predispute mandatory arbitration of those claims altogether. But the Supreme Court has foreclosed that option in Concepcion and Italian Colors.

And that leads us to the final, most practical benefit of our proposal: in addition to being reasonably tailored to the antitrust circumstances facing the merging companies, a merger condition imposed by the antitrust agencies is likely to survive judicial scrutiny. There is precedent for federal agencies imposing such a condition, and it is likely (though not certain) to be upheld by the courts. The Securities and Exchange Commission (SEC), for example, regularly requires companies filing for an initial public offering (IPO) to disavow any mandatory individual arbitration agreements in securities cases, even though arbitration is permissible in disputes between brokers and their

333 One limitation is that an existing dominant firm that does not merge with any company will not be bound by our proposal. While this is an unfortunate limitation, our proposal still improves the status quo.

334 See, e.g., Ross v. Am. Express Co., 35 F. Supp. 3d 407, 431 (S.D.N.Y. 2014). 
customers. ${ }^{335}$ The SEC first took this position in 1990, when an IPO applicant sought to include an arbitration provision in its governance documents. The SEC explained that:

[I]t would be contrary to the public interest to require investors who want to participate in the nation's equity markets to waive access to a judicial forum for vindication of federal or state law rights, where such a waiver is made through a corporate charter rather than through an individual investor's decision. ${ }^{336}$

Put another way, it is one thing to mandate that disputes in a one-to-one business relationship situated against the background of a competitive market must be resolved through arbitration; it is another to make access to a company's stock by the public at large contingent on their collective willingness to abandon valuable legal rights. ${ }^{337}$ The SEC has stuck by that policy, informing a registrant in 2012 that it would not approve an application that included an "agreement to require individual arbitration of any disputes relating to the agreement ..., including disputes arising under the federal securities laws." ${ }^{338}$ And it seems to have worked. Eisenberg and Miller find that only eleven percent of agreements filed with the SEC contain arbitration clauses. ${ }^{339}$

Our proposal could be implemented easily, without the need for new legislation or even new rulemaking by the agencies. The SEC, after all, did not adopt new rulemaking before restricting arbitration clauses; it simply began doing so under its enforcement authority. And while the no-antitrust-

\footnotetext{
335 The SEC long precluded mandatory arbitration between stock brokers and their customers, but the Supreme Court struck down those provisions in Shearson/Am. Express Inc. v. McMahon, 482 U.S. 220 (1987), and Rodriguez de Quijas v. Shearson/Am. Express, Inc., 490 U.S. 477 (1989).

336 Thomas L. Reisenberg, Arbitration and Corporate Governance: A Reply to Carl Schneider, INSIGHTS: CORP. \& SEC. L. ADVISOR, Aug. 1990, at 2, 2; see also Barbara Black, Arbitration of Investors' Claims Against Issuers: An Idea Whose Time Has Come?, 75 LAW \& CONTEMP. ProBs. 107, 116 (2012) (noting that Reisenberg's statement represented the SEC staff's position in 1990).

337 Cf. Wilko v. Swan, 346 U.S. 427, 438 (1953) (holding that the Securities Act of 1933 barred mandatory arbitration agreements that waived a right to judicial forum). The Shearson cases first limited Wilko to circumstances in which access to the courts was necessary to vindicate the substantive rights in the Securities Act, Shearson/American Express, Inc. v. McMahon, 482 U.S. 220 (1987), and later overruled it altogether, Rodriguez de Quijas v. Shearson/American Express, Inc., 490 U.S. 477 (1989). But Congress had the last word, providing in the Dodd-Frank Act that the SEC had the power to prohibit the use of pre-dispute arbitration agreements between "customers or clients of any broker, dealer, or municipal securities dealer.” Dodd-Frank Act, Pub. L. No. 111-203, § 921, 124 Stat. 1376, 1841 (2010) (codified at 15 U.S.C. $\$ 780(2012)$ ).

338 The Carlyle Group L.P., SEC Comment Letter, File No. 333-176685 (Feb. 3, 2012), https://www.sec.gov/Archives/edgar/data/1527166/000000000012006433/filename1.pdf [https://perma .cc/Y8XX-FQE8].

339 Theodore Eisenberg \& Geoffrey P. Miller, The Flight from Arbitration: An Empirical Study of Ex Ante Arbitration Clauses in the Contracts of Publicly Held Companies, 56 DEPAUL L. REv. 335, 335 (2007). While Eisenberg and Miller attribute this to a general reluctance on the part of publicly traded companies to use arbitration, the SEC's policy is likely to be a significant factor as well.
} 
class-action arbitration clause might not contribute directly to anticompetitive effects of the merger the agencies seek to remedy, it is directly related to the effective enforcement of post-merger conditions, as we established in Part III. In any event, it is well-established that antitrust agencies can include provisions in a consent decree that they could not obtain directly by suit. ${ }^{340}$

Consideration of our proposal's likely fate in the courts is especially relevant given the Supreme Court's recent hostility towards the rights of consumer plaintiffs. Since 1990, the Court has continued to cut back on consumer access to the courts, holding in Concepcion in 2011 that the Federal Arbitration Act preempted state laws that restricted predispute arbitration clauses that banned class actions. ${ }^{341}$ The Court also held that the class dispute could not be arbitrated either, requiring individual arbitrations instead, though that was based on a (strained) interpretation of the arbitration agreement rather than a holding that class disputes could never be arbitrated. ${ }^{342}$ And as noted above, Italian Colors extended that holding to conclude that arbitration clauses could trump federal as well as state public policy interests. ${ }^{343}$ All this is evidence of considerable hostility to consumer law enforcement, and a decided preference for arbitration, on the part of the current Supreme Court.

These decisions, however, do not foreclose our proposal. Each of those cases holds only that public policy does not preclude enforcement of an otherwise valid agreement to arbitrate protected under the Federal Arbitration Act. They do not hold that there is some legal right to impose an arbitration agreement in the first place that a party cannot negotiate away in a deal with the government. The SEC doesn't say "you can't impose predispute arbitration clauses," but rather "you can't impose predispute arbitration clauses if you want to take advantage of the federal securities laws to publicly trade stock." An antitrust condition would be even more clearly

\footnotetext{
340 See, e.g., Swift \& Co. v. United States, 276 U.S. 311, 331-32 (1928) ("Finally, it is urged that the decree is void, because the Attorney General had no power to agree to its entry. The argument is that the utmost limit of his authority was to agree to a decree which would prohibit the defendants from doing specific acts which constitute contracting, combining, conspiring, or monopolizing in violating of the anti-trust law; that he was without authority to enter into a contract by which citizens of the United States were prohibited absolutely and forever from engaging in the lawful business of conducting stockyards ... and by which many corporations and individuals would be forever taken out of the field of competition with others engaged in the same lines of business.... [W] do not find in the statutes defining the powers and duties of the Attorney General any such limitation on the exercise of his discretion as this contention involves. His authority to make determinations includes the power to make erroneous decisions as well as correct ones.").

341131 S. Ct. 1740,1753 (2011).

342 Id. at $1751-52$.

343133 S. Ct. 2304, 2310 (2013).
} 
a voluntary negotiation: "You can't impose predispute arbitration clauses that foreclose private antitrust lawsuits (including class actions) in federal court against your company if you want the government to waive its power to challenge your merger." While there are limits on the government's power to impose certain kinds of conditions - the doctrine of unconstitutional conditions being particularly relevant ${ }^{344}$ - these limits do not apply here. The government cannot take away or burden a constitutional right by imposing a requirement that a party waive that right. ${ }^{345}$ But there is no constitutional right to deny others effective access to the courts via contract. Even if the Supreme Court were correct that the Federal Arbitration Act ${ }^{346}$ encourages arbitration, ${ }^{347}$ that preference is a far cry from a constitutional right to impose arbitration agreements on others.

Some may object to the use of the merger approval process for nonmerger-related ends. ${ }^{348}$ For the reasons we articulated in Part III, we believe there is a connection between mergers and arbitration agreements and requiring arbitration of antitrust disputes is more problematic in more concentrated industries. But even if that were not true, we think the costs of imposing such a condition in the Hart-Scott-Rodino process will be minimal. It seems unlikely that companies will decide not to merge rather than agree to a deal, for instance. We emphasize that in a perfect world the Supreme Court would revisit Italian Colors. But since it seems unlikely to do so, our proposal is a second-best solution.

The condition that merging parties not require arbitration of antitrust claims in their contracts need not necessarily eliminate truly voluntary antitrust arbitration. Antitrust plaintiffs and defendants could still agree to have their case decided in binding arbitration after the dispute arises. An agreement to arbitrate an antitrust claim made after the dispute has arisen is less likely to be the product of coercion or a contract of adhesion. ${ }^{349}$ As Robert Pitofsky has noted, "there is no problem (as there often would be with

${ }^{344}$ For a discussion of the doctrine of unconstitutional conditions, see generally Kathleen M. Sullivan, Unconstitutional Conditions, 102 HARV. L. REV. 1413 (1989).

345 At least, sometimes it cannot. The unconstitutional conditions doctrine is complex, and lots of constitutional rights - like the right to free speech - clearly can be waived in a transaction with the government. See, e.g., Rust v. Sullivan, 500 U.S. 173, 198-99 (1991) (holding that the government could constitutionally restrict the free speech rights of doctors by preventing them from mentioning abortion as a condition of receiving federal funding).

3469 U.S.C. $\S \S 1-16(2012)$.

347 The Court is wrong. See Leslie, supra note 5.

348 See, e.g., Dissenting Statement of Commissioner Maureen K. Ohlhausen at 1-2, Robert Bosch $\mathrm{GmbH}$, No. 121-0081 (F.T.C. Nov. 26, 2012), https://www.ftc.gov/sites/default/files/ documents/public_statements/statement-commissioner-maureen-ohlhausen/ 121126boschohlhausenstatement.pdf [https://perma.cc/5SEC-QRQ4].

349 Coenen v. R.W. Pressprich \& Co., 453 F.2d 1209, 1215 (2d Cir. 1972). 
arbitration clauses) of a party, because of unequal bargaining power, agreeing to a waiver of future rights without knowing exactly what those rights will be." 350 Even some courts that refused to enforce predispute arbitration clauses allowed parties to agree to arbitrate antitrust claims after the dispute had arisen. ${ }^{351}$ In his Mitsubishi dissent, Justice Stevens noted that arbitration agreements "made after the parties have had every opportunity to evaluate the strength of their position, are obviously less destructive of the private treble-damages remedy that Congress provided. Thus, it may well be that arbitration as a means of settling existing disputes is permissible." ${ }^{352}$ Our proposal allows for the continued use of these post-dispute agreements.

Our proposal is ultimately quite modest. It merely increases the likelihood that the private antitrust claims Congress created more than a century ago will actually be heard in federal courts. ${ }^{353}$ This is more consistent with congressional intent than the current system. As Justice Stevens explained in his Mitsubishi dissent:

[A]n antitrust treble-damages case "can only be brought in a District Court of the United States." The determination that these cases are "too important to be decided otherwise than by competent tribunals" surely cannot allow private arbitrators to assume a jurisdiction that is denied to courts of the sovereign States. ${ }^{354}$

Some commentators may oppose our proposal by arguing that the objectives of merger review should be circumscribed. ${ }^{355}$ Our proposal, however, does not ask the antitrust agencies to use their powers of merger review to pursue non-antitrust goals. To the contrary, our proposal argues that in concentrated markets, antitrust agencies should try to prevent firms from using their postmerger market power to impose arbitration clauses that allow these firms to evade the effective antitrust scrutiny provided by private litigation. Many believe that Italian Colors was wrongly decided and should be overturned.

350 Pitofsky, supra note 107, at 1079.

351 See Cobb v. Lewis, 488 F.2d 41, 47 (5th Cir. 1974) (“"T] ']here is appropriately an 'exception' to this 'rule' against arbitration of antitrust issues for situations 'when the agreement to arbitrate is made after the dispute arises"') (quoting Cobb v. Network Cinema Corp., 339 F. Supp. 95, 99 (N.D. Ga. 1972)); id. at 47-49 (discussing cases); Allison, supra note 15, at 237.

352473 U.S. 614, 657 n.33 (1985) (Stevens, J., dissenting).

353 The proposal does not require that all antitrust claims be decided by federal judges because postdispute arbitration agreements are still enforceable.

354473 U.S. at 654 (Stevens, J., dissenting) (footnote omitted) (quoting Univ. Life Ins. Co. v. Unimarc Ltd., 699 F.2d 846, 850-51 (7th Cir. 1983)).

355 Cf. Dissenting Statement of Commissioner Maureen K. Ohlhausen, supra note 348, at 2 (opposing consent decree requiring licensing of standard-essential patents (SEPs) because "this enforcement policy appears to lack regulatory humility" and "implies that our judgment on . . SEPs is superior to that of these other institutions"). 
But one need not hold that view to see the wisdom of limiting antitrust arbitration in increasingly concentrated markets.

\section{CONCLUSION}

We do not, in short, propose to ban all antitrust arbitration, only blanket predispute requirements that deprive antitrust plaintiffs of an effective remedy. That is what the Court's Effective Vindication Doctrine purports to provide in theory. In the post-Italian Colors world, the antitrust agencies can take a substantial step towards truly effective vindication of antitrust rights by preventing defendants from forcing their customers to waive their right to sue in court.

The antitrust agencies are uniquely well suited to protect private antitrust enforcement - and perhaps class action enforcement more generally - in the set of cases that most need it. They have the power to prevent predispute blanket waivers of legal rights through mandatory arbitration of public law disputes. They should exercise that power as a condition of approving mergers, at least in doubtful cases. 